\title{
Prevention and Therapy of Preterm Birth. Guideline of the DGGG, OEGGG and SGGG (S2k Level, AWMF Registry Number 015/025, February 2019) - Part 2 with Recommendations on the Tertiary Prevention of Preterm Birth and the Management of Preterm Premature Rupture of Membranes
}

\author{
Prävention und Therapie der Frühgeburt. Leitlinie der DGGG, OEGGG \\ und SGGG (S2k-Niveau, AWMF-Registernummer 015/025, Februar \\ 2019) - Teil 2 mit Empfehlungen zur tertiären Prävention der Früh- \\ geburt und zum Management des frühen vorzeitigen Blasensprungs
}

Authors

Richard Berger ${ }^{1}$, Harald Abele ${ }^{2}$, Franz Bahlmann ${ }^{3}$, Ivonne Bedei ${ }^{4}$, Klaus Doubek ${ }^{5}$, Ursula Felderhoff-Müser ${ }^{6}$, Herbert Fluhr ${ }^{7}$, Yves Garnier ${ }^{8}$, Susanne Grylka-Baeschlin ${ }^{9}$, Hanns Helmer ${ }^{10}$, Egbert Herting ${ }^{11}$, Markus Hoopmann ${ }^{2}$, Irene Hösli ${ }^{12}$, Udo Hoyme ${ }^{13}$, Alexandra Jendreizeck ${ }^{14}$, Harald Krentel ${ }^{15}$, Ruben Kuon ${ }^{16}$, Wolf Lütje ${ }^{17}$, Silke Mader ${ }^{18}$, Holger Maul ${ }^{19}$, Werner Mendling ${ }^{20}$, Barbara Mitschdörfer ${ }^{14}$, Tatjana Nicin ${ }^{21}$, Monika Nothacker ${ }^{22}$, Dirk Olbertz ${ }^{23}$, Werner Rath ${ }^{24}$, Claudia Roll ${ }^{25}$, Dietmar Schlembach ${ }^{26}$, Ekkehard Schleußner ${ }^{27}$, Florian Schütz ${ }^{16}$, Vanadin Seifert-Klauss ${ }^{28}$, Susanne Steppat ${ }^{29}$, Daniel Surbek ${ }^{30}$

Affiliations

1 Frauenklinik, Marienhaus Klinikum Neuwied, Neuwied, Germany

2 Frauenklinik, Universitätsklinikum Tübingen, Tübingen, Germany

3 Frauenklinik, Bürgerhospital Frankfurt, Frankfurt am Main, Germany

4 Frauenklinik, Klinikum Frankfurt Höchst, Frankfurt am Main, Germany

5 Frauenarztpraxis, Wiesbaden, Germany

6 Klinik für Kinderheilkunde I/Perinatalzentrum, Universitätsklinikum Essen, Universität Duisburg-Essen, Essen, Germany

7 Frauenklinik, Universitätsklinikum Heidelberg, Heidelberg, Germany

8 Frauenklinik, Klinikum Osnabrück, Osnabrück, Germany

9 Zürcher Hochschule für angewandte Wissenschaften, Institut für Hebammen, Zürich, Switzerland

10 Universitätsklinik für Frauenheilkunde, Medizinische Universität Wien, Wien, Austria

11 Klinik für Kinder- und Jugendmedizin, Universitätsklinikum Schleswig-Holstein, Campus Lübeck, Lübeck, Germany

12 Frauenklinik, Universitätsspital Basel, Basel, Switzerland

13 Frauenklinik, Ilm-Kreis-Kliniken, Arnstadt, Germany 14 Bundesverband das frühgeborene Kind, Germany

15 Frauenklinik, Annahospital Herne, Elisabethgruppe Katholische Kliniken Rhein Ruhr, Herne, Germany

16 Frauenklinik, Universitätsklinikum Heidelberg, Heidelberg, Germany

17 Frauenklinik, Evangelisches Amalie Sieveking-Krankenhaus Hamburg, Hamburg, Germany

18 European Foundation for the Care of the Newborn Infants

19 Frauenklinik, Asklepios Kliniken Hamburg, Hamburg, Germany

20 Deutsches Zentrum für Infektionen in Gynäkologie und Geburtshilfe an der Frauenklinik, Helios Universitätsklinikum Wuppertal, Wuppertal, Germany

21 Frauenklinik, Klinikum Hanau, Hanau, Germany

22 Arbeitsgemeinschaft der Wissenschaftlichen Medizinischen Fachgesellschaften, Berlin, Germany

23 Abteilung Neonatologie und neonatologische Intensivmedizin, Klinikum Südstadt Rostock, Rostock, Germany

24 Emeritus, Universitätsklinikum Aachen, Aachen, Germany

25 Vestische Kinder- und Jugendklinik Datteln, Universität Witten/Herdecke, Datteln, Germany

26 Klinik für Geburtsmedizin, Klinikum Neukölln/Berlin Vivantes Netzwerk für Gesundheit, Berlin, Germany

27 Klinik für Geburtsmedizin, Universitätsklinikum Jena, Jena, Germany

28 Frauenklinik, Universitätsklinikum rechts der Isar München, München, Germany

29 Deutscher Hebammenverband, Germany

30 Universitäts-Frauenklinik, Inselspital, Universität Bern, Bern, Switzerland 
Key words

preterm birth, preterm labor, cervical insufficiency, preterm premature rupture of membranes

Schlüsselwörter

Frühgeburt, vorzeitige Wehentätigkeit, Zervixinsuffizienz, früher vorzeitiger Blasensprung

received $\quad 30.4 .2019$

accepted 30.4 .2019

Bibliography

DOI https://doi.org/10.1055/a-0903-2735

Geburtsh Frauenheilk 2019; 79: 813-833 @ Georg Thieme

Verlag KG Stuttgart · New York | ISSN 0016-5751

Correspondence

Prof. Dr. med. Richard Berger

Marienhaus Klinikum St. Elisabeth, Akademisches

Lehrkrankenhaus der Universitäten Mainz und Maastricht,

Klinik für Gynäkologie und Geburtshilfe

Friedrich-Ebert-Straße 59, 56564 Neuwied, Germany

richard.berger@marienhaus.de

$\circledast$

Deutsche Version unter:

https://doi.org/10.1055/a-0903-2735

\section{ABSTRACT}

Aims This is an official guideline of the German Society for Gynecology and Obstetrics (DGGG), the Austrian Society for Gynecology and Obstetrics (ÖGGG) and the Swiss Society for Gynecology and Obstetrics (SGGG). The aim of this guideline is to improve the prediction, prevention and management of preterm birth based on evidence obtained from recently pub- lished scientific literature, the experience of the members of the guideline commission and the views of self-help groups.

Methods The members of the participating medical societies and organizations developed Recommendations and Statements based on the international literature. The Recommendations and Statements were adopted following a formal consensus process (structured consensus conference with neutral moderation, voting done in writing using the Delphi method to achieve consensus).

Recommendations Part 2 of this short version of the guideline presents Statements and Recommendations on the tertiary prevention of preterm birth and the management of preterm premature rupture of membranes.

\section{ZUSAMMENFASSUNG}

Ziel Offizielle Leitlinie der Deutschen Gesellschaft für Gynäkologie und Geburtshilfe (DGGG), der Österreichischen Gesellschaft für Gynäkologie und Geburtshilfe (ÖGGG) und der Schweizerischen Gesellschaft für Gynäkologie und Geburtshilfe (SGGG). Ziel der Leitlinie ist es, die Prädiktion, die Prävention und das Management der Frühgeburt anhand der aktuellen Literatur, der Erfahrung der Mitglieder der Leitlinienkommission einschließlich der Sicht der Selbsthilfe evidenzbasiert zu verbessern.

Methoden Anhand der internationalen Literatur entwickelten die Mitglieder der beteiligten Fachgesellschaften und Organisationen Empfehlungen und Statements. Diese wurden in einem formalen Prozess (strukturierte Konsensuskonferenzen mit neutraler Moderation, schriftliche Delphi-Abstimmung) verabschiedet.

Empfehlungen Der Teil 2 dieser Kurzversion der Leitlinie zeigt Statements und Empfehlungen zur tertiären Prävention der Frühgeburt sowie zum Management des frühen vorzeitigen Blasensprungs.

\section{Guideline Information}

\section{Guidelines program}

For information on the guidelines program, please refer to the end of the guideline.

\section{Citation format}

Prevention and Therapy of Preterm Birth. Guideline of the DGGG, OEGGG and SGGG (S2k Level, AWMF Registry Number 015/025, February 2019) - Part 2 with Recommendations on the Tertiary Prevention of Preterm Birth and the Management of Preterm Premature Rupture of Membranes. Geburtsh Frauenheilk 2019; 79: 813-833

\section{Guideline documents}

The complete long version, a slide version of this guideline, a list of the conflicts of interest of all authors, and a guideline report on the methodological approach used, including the management of conflicts of interest, are available in German on the homepage of the AWMF: http://www.awmf.org/leitlinien/detail/II/015-025.html 


\section{Guideline authors ( Table 1)}

- Table 1 The following medical societies/working groups/organizations/associations were interested in participating in the compilation of the text of the guideline and in the consensus conference, and they nominated representatives to attend the consensus conference.

\begin{tabular}{|c|c|}
\hline $\begin{array}{l}\text { Author } \\
\text { Mandate holder }\end{array}$ & $\begin{array}{l}\text { DGGG working group (AG)/AWMF/non-AWMF } \\
\text { medical society/organization/association }\end{array}$ \\
\hline Prof. Dr. Harald Abele & DGGG - Arbeitsgemeinschaft für Geburtshilfe und Pränatalmedizin (AGG) - Sektion Frühgeburt \\
\hline Prof. Dr. Franz Bahlmann & Deutsche Gesellschaft für Ultraschall in der Medizin e. V. (DEGUM) \\
\hline Dr. Ivonne Bedei & DGGG - Arbeitsgemeinschaft Kinder- und Jugendgynäkologie e. V. (AGKJ) \\
\hline Prof. Dr. Richard Berger & Deutsche Gesellschaft für Gynäkologie und Geburtshilfe (DGGG) \\
\hline Dr. Klaus Doubek & Berufsverband der Frauenärzte e. V. (BVF) \\
\hline Prof. Dr. Ursula Felderhoff-Müser & Gesellschaft für neonatale und pädiatrische Intensivmedizin (GNPI) \\
\hline Prof. Dr. Herbert Fluhr & DGGG - Arbeitsgemeinschaft für Immunologie in Gynäkologie und Geburtshilfe (AGIM) \\
\hline PD Dr. Dr. Yves Garnier & DGGG - Arbeitsgemeinschaft für Geburtshilfe und Pränatalmedizin (AGG) - Sektion Frühgeburt \\
\hline Dr. Susanne Grylka-Baeschlin & Deutsche Gesellschaft für Hebammenwissenschaften (DGHWi) \\
\hline Prof. Dr. Hanns Helmer & Österreichische Gesellschaft für Gynäkologie und Geburtshilfe (OEGGG) \\
\hline Prof. Dr. Egbert Herting & Deutsche Gesellschaft für Kinder- und Jugendmedizin (DGKJ) \\
\hline Prof. Dr. Markus Hoopmann & DGGG - Arbeitsgemeinschaft für Ultraschalldiagnostik in Gynäkologie und Geburtshilfe (ARGUS) \\
\hline Prof. Dr. Irene Hösli & Schweizerische Gesellschaft für Gynäkologie und Geburtshilfe (SGGG) \\
\hline Prof. Dr. Dr. h. c. Udo Hoyme & DGGG - Arbeitsgemeinschaft für Infektionen und Infektionsimmunologie (AGII) \\
\hline Alexandra Jendreizeck & Bundesverband "Das frühgeborene Kind" [Federal Association “The preterm Child"] \\
\hline Dr. Harald Krentel & DGGG - Arbeitsgemeinschaft für Frauengesundheit in der Entwicklungszusammenarbeit (FIDE) \\
\hline PD Dr. Ruben Kuon & Deutsche Gesellschaft für Gynäkologie und Geburtshilfe (DGGG) \\
\hline Dr. Wolf Lütje & DGGG - Deutsche Gesellschaft für psychosomatische Frauenheilkunde und Geburtshilfe e. V. (DGPFG) \\
\hline Silke Mader & European Foundation for the Care of the Newborn Infants (EFCNI) \\
\hline PD Dr. Holger Maul & Deutsche Gesellschaft für Perinatale Medizin (DGPM) \\
\hline Prof. Dr. Werner Mendling & DGGG - Arbeitsgemeinschaft für Infektionen und Infektionsimmunologie (AGII) \\
\hline Barbara Mitschdörfer & Bundesverband "Das frühgeborene Kind" [Federal Association "The preterm Child"] \\
\hline Tatjana Nicin & Deutscher Hebammenverband (DHV) \\
\hline Dr. Dirk Olbertz & Gesellschaft für neonatale und pädiatrische Intensivmedizin (GNPI) \\
\hline Prof. Dr. Werner Rath & Deutsche Gesellschaft für Pränatal- und Geburtsmedizin (DGPGM) \\
\hline Prof. Dr. Claudia Roll & Deutsche Gesellschaft für Perinatale Medizin (DGPM) \\
\hline PD Dr. Dietmar Schlembach & DGGG - Arbeitsgemeinschaft für Geburtshilfe und Pränatalmedizin (AGG) - Sektion Präeklampsie \\
\hline Prof. Dr. Ekkehard Schleußner & DGGG - Deutsche Gesellschaft für psychosomatische Frauenheilkunde und Geburtshilfe e. V. (DGPFG) \\
\hline Prof. Dr. Florian Schütz & DGGG - Arbeitsgemeinschaft für Immunologie in Gynäkologie und Geburtshilfe (AGIM) \\
\hline Prof. Dr. Vanadin Seifert-Klauss & DGGG - Deutsche Gesellschaft für Gynäkologische Endokrinologie und Fortpflanzungsmedizin e. V. (DGGEF) \\
\hline Susanne Steppat & Deutscher Hebammenverband (DHV) \\
\hline Prof. Dr. Daniel Surbek & Schweizerische Gesellschaft für Gynäkologie und Geburtshilfe (SGGG) \\
\hline
\end{tabular}

\section{Abbreviations}

AFP alpha-fetoprotein

AUC area under the curve

$\mathrm{Cl} \quad$ confidence interval

COX cyclooxygenase

CPAP continuous positive airway pressure

CRP C-reactive protein

CTG cardiotocography

fFN fetal fibronectin
FIRS

GBS

GW

IGFBP-1

IL-6

NEC

$\mathrm{NICU}$

$\mathrm{NNH}$

NNT fetal inflammatory response syndrome group B streptococcus week of gestation insulin-like growth factor-binding protein-1 interleukin-6 necrotizing enterocolitis neonatal intensive care unit number needed to harm number needed to treat 
OR odds ratio

17-OHPC 17 $\alpha$-hydroxyprogesterone caproate

PAMG-1 placental alpha microgobulin-1

phIGFBP-1 phosphorylated insulin-like growth factor-binding

protein-1

$\mathrm{PIVH} \quad$ periventricular/intraventricular hemorrhage

PPROM preterm premature rupture of membranes

PVL periventricular leukomalacia

RDS respiratory distress syndrome

RR relative risk

s/p status post

TCO total cervical occlusion

TNF- $\alpha$ tumor necrosis factor alpha

Triple I intrauterine inflammation or infection or both

\section{Guideline Application}

\section{Purpose and objectives}

This guideline aims to improve both the outpatient and the inpatient care of patients at imminent risk of preterm birth in order to reduce the rate of preterm births. If preterm birth cannot be prevented, the aim is to reduce perinatal and neonatal morbidity and mortality. This should lead to improvements in the psychomotor and cognitive development of children born preterm.

\section{Targeted areas of patient care}

Outpatient and/or inpatient care

\section{Target user groups/target audience}

The recommendations of this guideline are aimed at gynecologists in private practice, gynecologists in hospitals, pediatricians in hospitals, midwives in private practice and midwives in hospitals. Other target user groups include advocacy groups for affected women and children, nursing staff (obstetrics/postnatal care, pediatric intensive care), medical and scientific societies and professional associations, institutions for quality assurance (e.g. IQTIG), healthcare policy institutions and decision-makers at the federal and state level, funding agencies and payers.

\section{Adoption and period of validity}

The validity of this guideline was confirmed by the executive boards of the participating medical societies, working groups, organizations and associations as well as by the executive boards of the DGGG, the SGGG and the OEGGG and the DGGG/OEGGG/ SGGG guidelines commission in February 2019 and was thus confirmed in its entirety. This guideline is valid from 1 February 2019 through to 31 January 2022. Because of the contents of this guideline, this period of validity is only an estimate. The guideline may need to be updated earlier in urgent cases. If the guideline continues to mirror current knowledge, its period of validity may also be extended.

\section{Method}

\section{Basic principle}

The method used to prepare this guideline was determined by the class to which this guideline was assigned. The AWMF Guidance Manual (version 1.0) has set out the respective rules and requirements for different classes of guidelines. Guidelines are differentiated into lowest (S1), intermediate (S2) and highest (S3) class. The lowest class is defined as a set of recommendations for action compiled by a non-representative group of experts. In 2004, the S2 class was divided into two subclasses: a systematic evidencebased subclass (S2e) and a structural consensus-based subclass (S2k). The highest S3 class combines both approaches. This guideline is classified as: $\mathbf{S} \mathbf{2 k}$

\section{Grading of recommendations}

Grading of evidence and grading of recommendations is not envisaged for S2k-level guidelines. The individual Statements and Recommendations are differentiated by syntax, not by symbols ( Table 2).

\begin{tabular}{|c|c|}
\hline Level of recommendation & Syntax \\
\hline Strong recommendation, highly binding & must/must not \\
\hline Simple recommendation, moderately binding & should/should not \\
\hline Open recommendation, not binding & may/may not \\
\hline
\end{tabular}

In addition to the level of evidence, the above listed classification of "Recommendations" also takes account of the clinical relevance of the underlying studies and the various measures/factors which were not included in the grading of evidence, such as the choice of patient cohort, intention-to-treat or per-protocol outcome analyses, medical and ethical practice when dealing with patients, country-specific applicability, etc.

\section{Statements}

Scientific statements given in this guideline which do not consist of any direct recommendations for action but are simple statements of fact are referred to as "Statements". It is not possible to provide any information about the grading of evidence for these Statements.

\section{Achieving consensus and strength of consensus}

As part of the structured process to achieve consensus ( $\mathrm{S} 2 \mathrm{k} / \mathrm{S} 3$ level), authorized participants attending the session vote on draft Statements and Recommendations. This can lead to significant changes in the wording, etc. Finally, the extent of consensus is determined based on the number of participants ( $\triangleright$ Table 3 ). 
- Table 3 Grading of strength of consensus.

\begin{tabular}{|l|l|l|}
\hline Symbol & Strength of consensus & Extent of agreement in percent \\
\hline+++ & Strong consensus & $>95 \%$ of participants agree \\
\hline++ & Consensus & $>75-95 \%$ of participants agree \\
\hline+ & Majority agreement & $>50-75 \%$ of participants agree \\
\hline- & No consensus & $<51 \%$ of participants agree \\
\hline
\end{tabular}

\section{Expert consensus}

As the name already implies, this term refers to consensus decisions taken with regard to specific Recommendations/Statements made without a prior systematic search of the literature (S2k) or for which evidence is lacking (S2e/S3). The term "expert consensus" (EC) used here is synonymous with terms used in other guidelines such as "good clinical practice" (GCP) or "clinical consensus point" (CCP). The strength of the recommendation is graded as previously described in the chapter "Grading of recommendations", i.e., purely semantically ("must"|"must not" or "should"| "should not" or "may"|“may not") without the use of symbols.

\section{Addendum of the OEGGG}

To 6.9.1 Mode of delivery depending on fetal presentation and position

The Austrian Society of Gynecology and Obstetrics (OEGGG) is of the opinion that there is no clinical or scientific basis for the Recommendation that cesarean section should be the preferred mode of delivery based on an assumed lower risk of perinatal cerebral hemorrhage. The OEGGG is of the opinion that the mode of delivery of infants at the limit of viability (GW $22+0$ bis $24+6$ ) must be adapted to take the individual maternal and fetal clinical situation into account. For singletons at the limit of viability and in cephalic presentation, the OEGGG recommends an individualized management of delivery, which takes the maternal and fetal clinical situation into account and where the clinical decision process also includes the option of vaginal delivery as the mode of delivery [1].

\section{To 6.6.5 Application of antenatal steroids before late preterm delivery}

Based on the results of the ALPS trial [2] and the recommendations of the Society for Maternal Fetal Medicine (SMFM), the OEGGG is of the opinion that the administration of antenatal steroids in GW $34+0$ to GW $36+6$ may be considered, in accordance with the specifications of the SMFM.

\section{Addendum of the SGGG}

\section{To 6.6. Administration of antenatal steroids}

The opinion of the SGGG on the issues in this chapter is presented in SGGG Expert Letter No. 56, which discusses the indications for glucocorticoid therapy to promote antenatal lung maturation and the appropriate doses when preterm birth is imminent (only available in German: "Glucocorticoidtherapie zur antenatalen Lungenreifung bei drohender Frühgeburt: Indikationen und Dosierung"). Reasoning: The evidence-based recommendations in Switzerland differ slightly from those given in this guideline, particularly with regard to the administration of antenatal glucocorticoids in gestational weeks $34+0$ to $36+0$ [3].

\section{To 1. Definition and Epidemiology (and various other chapters: 6.9.1., 6.9.6., 6.9.7., 8.8., 8.9.)}

As regards care at the limits of viability, please refer to the recommendations for Switzerland which were developed together with neonatologists. Reasoning: The recommendations for Switzerland diverge in many points from the recommendations for Germany. They are currently being revised [4].

\section{To 6.2. Tocolysis}

With regard to tocolytic drugs, the use of beta-mimetics for tocolysis has been approved in Switzerland and they can be used as the tocolytic drug of first choice; see also SGGG Expert Letter No. 41 on tocolysis for preterm labor (only available in German: "Tokolyse bei vorzeitiger Wehentätigkeit"). Reasoning: The recommendations for Switzerland differ in many points from the recommendations for Germany [5].

\section{To 8.8 Clinical management before GW 22}

The option of terminating the pregnancy should be mentioned to patients with a poor prognosis. Reasoning: The option of terminating the pregnancy by inducing the birth in cases where there is a serious physical or psychological risk to the mother is not mentioned in the guideline, even though it is clinically important.

\section{Guideline}

\section{Tertiary Prevention \\ 6.1 Bed rest}

\begin{tabular}{l} 
Consensus-based Statement 6.521 \\
\hline Expert consensus \\
There is currently no data which can confirm that bed rest reduces the rate \\
of preterm births. However, bed rest does increase the maternal risk of \\
thrombosis and contributes to the development of muscular atrophy and \\
osteoporosis. \\
{$[6-10]$}
\end{tabular}

\subsection{Tocolysis}

\begin{tabular}{l} 
Consensus-based Recommendation 6.E18 \\
\hline Expert consensus \\
The aim of tocolysis must be to prolong the pregnancy by at least 48 hours. \\
This additional period would make it possible to administer antenatal \\
steroids and carry out an in-utero transfer to a perinatal center with a \\
neonatal intensive care unit.
\end{tabular}




\subsubsection{Indications}

Consensus-based Recommendation 6.E19
$\begin{aligned} & \text { Expert consensus } \\ & \text { Strength of consensus +++ }\end{aligned}$
Tocolytic therapy should be administered if the patient has spontaneous,
regular, preterm contractions of $\geq 4 / 20$ min with shortening of the
functional cervical length (transvaginal measurement) and/or opening
of the cervix.

\section{Consensus-based Statement 6.522}

\begin{tabular}{|l|l|} 
Expert consensus & Strength of consensus +++
\end{tabular}

If the indications are present and contra-indications have been excluded, tocolysis is indicated in the period between GW $22+0$ and GW $33+6$.

\begin{tabular}{l}
\begin{tabular}{l} 
Consensus-based Statement 6.523 \\
\hline Expert consensus
\end{tabular} Strength of consensus +++ \\
\hline In cases of premature labor with cervical dilation, tocolytic therapy (beta \\
sympathomimetics, atosiban, nifedipine, indomethacin, NO donors) can \\
delay the birth by 48 h in $75-93 \%$ of cases and by 7 days in $62-78 \%$ of cases. \\
\hline 11,12$]$ \\
\hline
\end{tabular}

\subsubsection{Drugs}

Consensus-based Recommendation 6.E20

\section{Expert consensus}

Strength of consensus ++

Because of the significantly higher rate of maternal side effects (beta sympathomimetics) compared to other tocolytic drugs and the lack of evidence confirming its tocolytic efficacy (magnesium sulfate), beta sympathomimetics and magnesium sulfate should no longer be used for tocolysis.

Of all the tocolytic drugs, beta sympathomimetics have the greatest rate of maternal (up to $80 \%$ cardiovascular) and fetal side effects as well as requiring the most monitoring [12]. There is also the additional problem of lung edema which occurs in around 1/ 350 applications [13]. They should therefore no longer be used for tocolysis [14].

The data on the use of magnesium sulfate as a tocolytic drug is controversial. Meta-analyses [11,12] showed that magnesium sulfate was an effective tocolytic in terms of prolonging the pregnancy by 48 hours compared to placebo (OR 2.46; $95 \% \mathrm{Cl}$ : $1.58-$ 4.94); however, this flies in the face of the results and statements of the 2014 Cochrane Review [15], which were generated using 37 studies with 3571 pregnant women. According to the Cochrane Review, magnesium sulfate was not more effective than placebo or even no therapy at prolonging pregnancy for more than 48 hours and does not reduce the rate of preterm births. However, the tocolytic efficacy of magnesium sulfate depends in the dose, which in turn has an impact on the incidence of maternal side effects. International guidelines no longer recommend using magnesium sulfate for tocolysis [16-18].

\section{Consensus-based Recommendation 6.E21}

Expert consensus

Strength of consensus ++

After considering their efficacy and side effects profile, calcium antagonists (nifedipine), oxytocin-receptor antagonists (atosiban) and COX inhibitors (indomethacin) should be used preferentially for tocolysis, even though some have not yet been approved for use.

$[11,12]$

\subsubsection{Combining several tocolytics}

\begin{tabular}{|c|c|}
\hline \multicolumn{2}{|c|}{ Consensus-based Recommendation 6.E22 } \\
\hline Expert consensus & Strength of consensus +++ \\
\hline \multicolumn{2}{|c|}{$\begin{array}{l}\text { Based on current data, combining different tocolytics is associated } \\
\text { with significantly increased rates of maternal side effects compared to } \\
\text { administering a single tocolytic, and as there are no data confirming any } \\
\text { increase in efficacy, combining different tocolytics should be avoided. }\end{array}$} \\
\hline$[13,19]$ & \\
\hline
\end{tabular}

\section{Consensus-based Recommendation 6.E23}

Expert consensus Strength of consensus +++

Tocolytics should not be administered in combination with oral/vaginal progesterone ("adjunctive tocolysis"), because data on this issue is still insufficient.

[20]

\subsubsection{Tocolysis for extremely preterm birth, multiple pregnancy and intrauterine growth restriction}

\section{Consensus-based Statement 6.S24}

\begin{tabular}{l|l} 
Expert consensus & Strength of consensus +++
\end{tabular}

Evidence from randomized controlled studies on the benefits of tocolytics for extremely preterm birth, multiple pregnancy and intrauterine growth restriction is lacking. The decision whether to administer tocolytics in such cases must be made on a case-by-case basis.

[21]

\subsubsection{Long-term tocolysis}

\section{Consensus-based Recommendation 6.E24}

Expert consensus Strength of consensus +++

According to the information currently available, long-term or maintenance tocolysis (generally defined as tocolysis for more than $48 \mathrm{~h}$ ) should not be used to reduce the rate of preterm births or neonatal morbidity and mortality rates.

$[22-25]$ 


\section{Consensus-based Recommendation 6.E25}

Expert consensus

Strength of consensus +++

After tocolysis, pregnant women with a singleton pregnancy should not be given progesterone to maintain the pregnancy and prevent preterm birth.

A meta-analysis carried out in 2017 which selectively included high-quality studies on this issue found that the use of progesterone for maintenance tocolysis did not significantly reduce the rate of preterm births before the 37th week of gestation (OR 1.23, 95\% Cl: 0.91-1.67) [26].

6.4 Cervical pessary for shortened cervical length after premature labor

\begin{tabular}{l} 
Consensus-based Statement $\mathbf{6 . S 2 5}$ \\
\hline Expert consensus \\
\hline There is some evidence from a prospective randomized study that \\
placement of a cervical pessary in pregnant women previously treated for \\
premature labor who have a shortened cervical length as measured by \\
transvaginal ultrasound $(<25 \mathrm{~mm}$ between GW $24+0$ and GW $29+6$; \\
$<15 \mathrm{~mm}$ between GW $30+0$ and GW $33+6)$ may reduce the rate of \\
preterm births.
\end{tabular}

Pratcorona et al. recently published a prospective randomized study which included 357 patients between GW $24+0$ and GW $33+6$ [27]. If patients had a shortened cervical length $(\leq 25 \mathrm{~mm}$ between GW $24+0$ and GW $29+6$; $\leq 15$ mm between GW $30+0$ and GW $33+6) 48$ hours after being treated for premature labor, they were managed either by placing a cervical pessary or by standard protocol. The primary study outcome, in this case, the preterm birth rate before the 34th week of gestation, did not differ significantly between groups (10.7 vs. $13.7 \%$; RR 0.78 [95\% Cl: 0.45-1.38]). However, the preterm birth rate before the 37 th week of gestation was significantly lower after placement of a cervical pessary ( 14.7 vs. $25.1 \%$; RR 0.58 [ $95 \% \mathrm{Cl}$ : $0.38-0.90]$ ) as was the number of patients readmitted to hospital after previously being treated for premature labor (4.5 vs. 20.0\%; RR 0.23 [95\% Cl: 0.11-0.47]). However, these results could not be confirmed in the APOSTEL VI trial [28].

\subsection{Administration of antibiotics for premature labor}

\section{Consensus-based Recommendation 6.E26}

\begin{tabular}{|l|l|} 
Expert consensus & Strength of consensus +++
\end{tabular}

Cases of premature labor without rupture of membranes must not be treated with antibiotics with the goal of prolonging the pregnancy or reducing neonatal morbidity.
Meta-analyses found that the administration of antibiotics to cases with premature labor and no rupture of membranes had no effect on the duration of the pregnancy, the preterm birth rate, respiratory distress syndrome or neonatal sepsis $[29,30]$. Given these findings, the potential risks of administering antibiotics when their administration is not indicated need to be discussed.

\subsection{Administration of antenatal steroids}

\subsubsection{Administration and dosage}

\section{Consensus-based Recommendation 6.E27}

Expert consensus

Strength of consensus +++

Antenatal steroids must be administered to women at imminent risk of preterm birth before GW $34+0$, with treatment consisting of $2 \times 12 \mathrm{mg}$ betamethasone administered IM at an interval of $24 \mathrm{~h}$ (alternatively: dexamethasone, $4 \times 6 \mathrm{mg}$ every $12 \mathrm{~h}$ ).

[31]

\subsubsection{Starting in which week of gestation?}

\section{Consensus-based Recommendation 6.E28}

\section{Expert consensus}

Strength of consensus +++

Antenatal steroids should also be administered in cases at imminent risk of preterm birth < GW $24+0$ if maximum therapy in a neonatal intensive care unit is planned.

A recently published meta-analysis found 8 non-randomized studies on this issue [32]. The impact on neonatal mortality and morbidity of a single dose of corticosteroids administered in the period GW $22+0$ to GW $23+6$ is shown in > Tables $\mathbf{4}$ and $\mathbf{5}$.

While neonatal mortality was significantly reduced after a single dose of corticosteroids, it apparently had no effect on morbidity. Given the rapid recent progress in the field of neonatal intensive care, prospective randomized studies on this issue are urgently required.

- Table 4 Effects of antenatal steroids on the outcome of infants between GW $22+0$ and GW $22+6$ [32].

\begin{tabular}{|l|l|l|}
\hline $\mathbf{G W} \mathbf{2 2}+\mathbf{0}-\mathbf{G W} \mathbf{2 2}+\mathbf{6}$ & $\mathbf{O R}$ & $\mathbf{9 5 \%} \mathbf{C I}$ \\
\hline Neonatal mortality & 0.58 & $0.38-0.89$ \\
\hline $\begin{array}{l}\text { Intraventricular cerebral hemorrhage } \\
\text { (grade III-IV) or periventricular leukomalacia }\end{array}$ & 1.03 & $0.55-1.93$ \\
\hline Chronic pulmonary disease & 1.19 & $0.52-2.73$ \\
\hline Necrotizing enterocolitis (> stage II) & 0.59 & $0.03-12.03$ \\
\hline
\end{tabular}




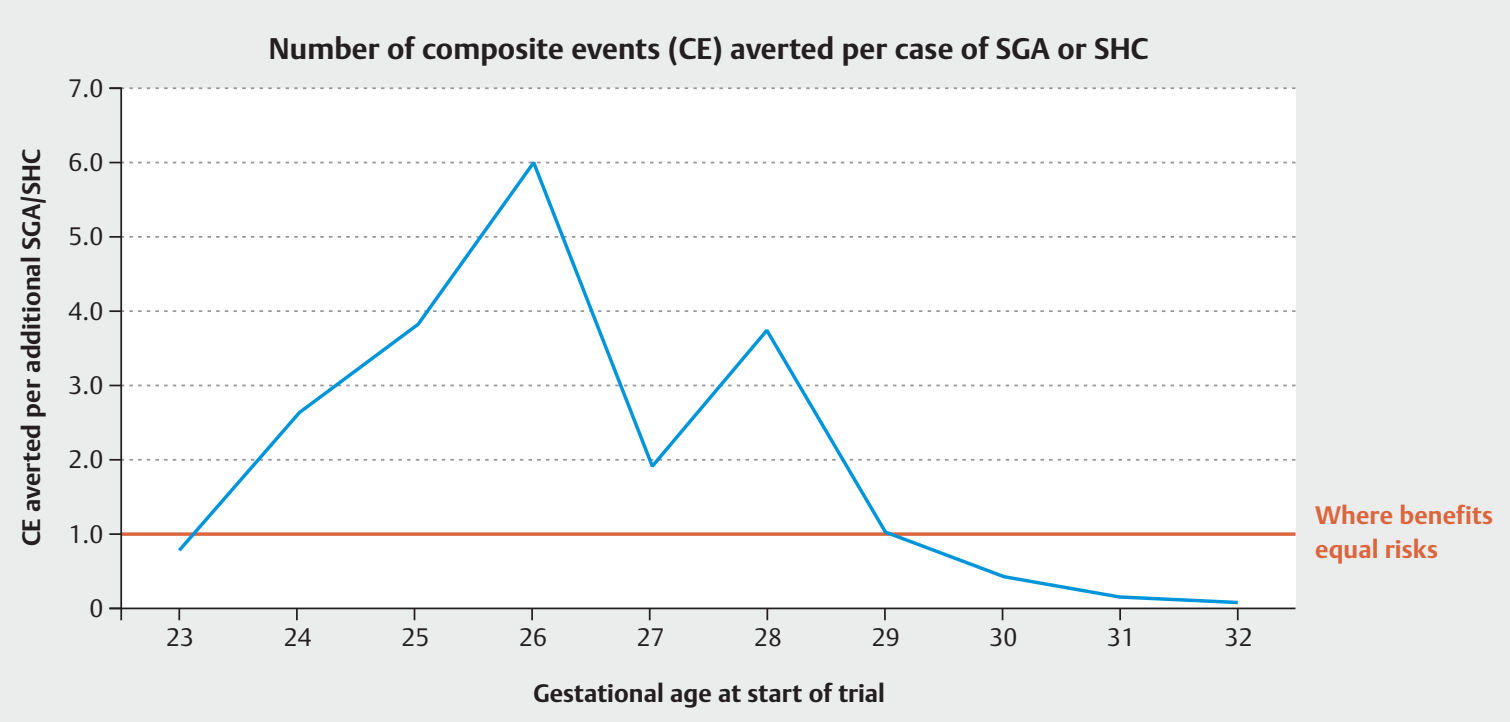

The $x$-axis shows the gestational age at entry; the $y$-axis shows the number of composite events that were averted per case of SGA/SHC. A gestational age risk benefit threshold is seen at 29 weeks' gestation, when the risk equals the benefits.

SGA: small for gestational age; SHC: small head circumference; CE: RDS, chronic lung disease (CLD), severe PIVH, PVL, bronchopulmonary dysplasia (BPD), or stillbirth

- Fig. 1 Benefits of administering antenatal steroids according to gestational age [33]

- Table 5 Effects of antenatal steroids on the outcome of infants between GW $23+0$ and GW $23+6$ [32].

\begin{tabular}{|l|l|l|}
\hline GW $\mathbf{2 3}+\mathbf{0}-\mathbf{G W} \mathbf{2 3}+\mathbf{6}$ & $\mathbf{O R}$ & $\mathbf{9 5} \% \mathbf{C I}$ \\
\hline Neonatal mortality & 0.50 & $0.42-0.58$ \\
\hline $\begin{array}{l}\text { Intraventricular cerebral hemorrhage } \\
\text { (grade III-IV) or periventricular leukomalacia }\end{array}$ & 0.75 & $0.55-1.03$ \\
\hline Chronic pulmonary disease & 0.94 & $0.59-1.51$ \\
\hline Necrotizing enterocolitis (> stage II) & 0.93 & $0.66-1.32$ \\
\hline
\end{tabular}

\subsubsection{Repeat administration of antenatal steroids}

\section{Consensus-based Recommendation 6.E29}

\section{Expert consensus}

Strength of consensus +++

If steroids are administered to women before the $29+0$ week of gestation because of an imminent risk of preterm birth and steroids were administered more than 7 days previously, a further dose of steroids may be administered after the patient has been re-assessed if the imminent risk of preterm birth is increasing.

Zephyrin and colleagues used a Markov model to investigate how to achieve the right balance between risks and benefits with repeat administration of antenatal steroids [33]. The improved neonatal outcomes after multiple glucocorticoid administrations were set against the risk of fetal growth restriction. After $29+0$ weeks of gestation, a repeat administration of antenatal steroids was associated with increasing risks for the infant ( $\triangleright$ Fig. 1). Any repeat administration of antenatal steroids should therefore be limited to cases with a very low gestational age $(<$ GW $29+0)$.

\subsubsection{Timing of antenatal steroid administration}

\section{Consensus-based Statement 6.S26}

\begin{tabular}{|l|l|}
\hline Expert consensus & Strength of consensus +++
\end{tabular}

The timing of and indication for administering antenatal steroids must be carefully weighed up, as neonatal morbidity and mortality can only be reduced in the period between $24 \mathrm{~h}$ and 7 days after the first administration. There is some evidence that administering antenatal steroids already has an effect before $24 \mathrm{~h}$.

There are now a number of cohort studies which show that perinatal morbidity and mortality depend significantly on the timing of lung maturity [34-36]. An example of this is shown in $\mathbf{r} \mathbf{F i g . ~} \mathbf{2}$, which depicts the neonatal survival of infants born preterm at $\leq 26$ weeks of gestation [36].

\section{Consensus-based Recommendation 6.E30}

\section{Expert consensus \\ Strength of consensus +++}

Patients with premature contractions and a cervical length of $>30 \mathrm{~mm}$ or 15-30 $\mathrm{mm}$ as measured by transvaginal ultrasound and who additionally test negative for fibronectin, phIGFBP-1 and PAMG-1 should not be given antenatal steroids just because of the contractions, as the risk of preterm birth in the next 7 days is low $(<5 \%)$.

$[37,38]$ 


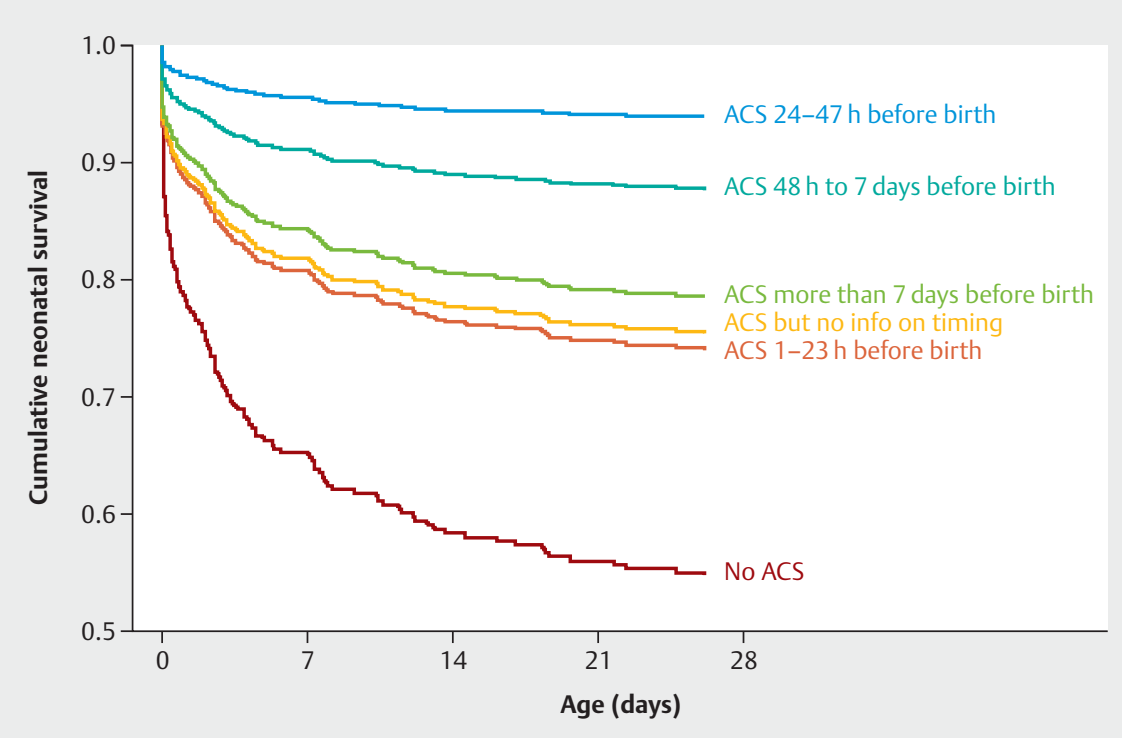

- Fig. 2 Survival of very immature infants (<26th week of gestation) according to the timing of antenatal steroid administration [36].

\section{Consensus-based Recommendation 6.E31}

\section{Expert consensus}

Strength of consensus +++

So-called rapid maturation, consisting of the administration of a second dose of betamethasone after just $12 \mathrm{~h}$ rather than after $24 \mathrm{~h}$, should be avoided as this significantly increases the risk of necrotizing enterocolitis.

[39]

\subsubsection{Administration of antenatal steroids and late preterm birth}

\section{Consensus-based Recommendation 6.E32}

\begin{tabular}{l|l} 
Expert consensus & Strength of consensus ++
\end{tabular}

Administering antenatal steroids to patients between GW $34+0$ and GW $36+5$ with an imminent risk of preterm birth should currently be avoided as there are still no studies on the impact this can have on the children's psychomotor development later on.

The ALPS trial found a significant reduction in neonatal respiratory distress in children born in late preterm at GW $34+0$ to GW $36+5$, whose mothers were given $2 \times 12 \mathrm{mg}$ betamethasone IM antenatally [2]. The ASTECS trial, which studied pregnant women who underwent elective cesarean section at term, also reported a significant reduction in RDS in children born to mothers who received $2 \times 12 \mathrm{mg}$ betamethasone antenatally [40]. However, at a school assessment carried out by teachers 10 years later, it was found that significantly more children from the intervention group were in the lower performance quartile and fewer children were in the top performance quartile [41]. No follow-up examinations of the children in the ALPS trial have been carried out to date. Because of this, no antenatal corticoids should be administered to this group of patients for the time being.

\subsection{Emergency cerclage}

\begin{tabular}{l}
\hline Consensus-based Recommendation 6.E33 \\
\hline Expert consensus \\
\hline An emergency cerclage may be placed in women with a singleton \\
pregnancy and cervical dilation of more than $1 \mathrm{~cm}$ before GW $24+0$ with \\
the goal of significantly prolonging the pregnancy.
\end{tabular}

\section{Consensus-based Recommendation 6.E34}

Expert consensus

Strength of consensus +++

Women treated with emergency cerclage should receive indomethacin and antibiotics perioperatively.

A meta-analysis published in 2015 ( $n=772$ women from 11 studies, $n=496$ underwent emergency cerclage placement, $n=276$ were managed expectantly) found a significant prolongation of pregnancy and reduction of perinatal mortality after placement of an emergency cerclage for cervical dilation (duration of pregnancy: plus 5.4 weeks, perinatal mortality reduced from $58.5 \%$ to $29.1 \%$ ) [42]. The administration of indomethacin and cefazolin increased the percentage of women who did not give birth within the following 4 weeks (92.3 vs. 62.5\%) [43]. 


\subsubsection{Longitudinal uterine incision for cesarean section}

Expert consensus

\section{Strength of consensus +++}

Periventricular/intraventricular hemorrhage (PIVH) and periventricular leukomalacia (PVL)/diffuse cerebral white matter injury are typical forms of brain injury found in survivors of preterm birth.

[44]

\subsubsection{Magnesium}

\section{Consensus-based Recommendation 6.E35}

\section{Expert consensus}

Strength of consensus +++

Magnesium may be administered intravenously for fetal neuroprotection to patients < GW 32 at imminent risk of preterm birth.

$[45,46]$

Treatment should be started with a bolus of 4-6 $\mathrm{g}$ administered over $30 \mathrm{~min}$, followed by a maintenance dose of $1-2 \mathrm{~g}$ for $12 \mathrm{~h}$. The aim is to double the magnesium levels in maternal serum. If the birth does not occur within $12 \mathrm{~h}$, magnesium may be administered again later on when preterm birth is once again imminent.

\subsubsection{Delayed cord clamping}

\begin{tabular}{|c|c|}
\hline \multicolumn{2}{|c|}{ Consensus-based Recommendation $6 . E 36$} \\
\hline Expert consensus & Strength of consensus +++ \\
\hline \multicolumn{2}{|c|}{$\begin{array}{l}\text { Cord clamping of infants born preterm should be delayed or umbilical cord } \\
\text { milking should be carried out. }\end{array}$} \\
\hline [47-49] & \\
\hline
\end{tabular}

6.9

Delivery

\subsubsection{Delivery depends on fetal presentation}

\section{Consensus-based Recommendation 6.E37}

\section{Expert consensus}

\section{Strength of consensus ++}

Delivery by cesarean section may be considered after carefully weighing up the risk/benefits in each individual case if the fetus is aged < GW $30+0$ and in cephalic presentation.

$[50-63]$
Consensus-based Statement 6.527

\section{Consensus-based Recommendation 6.E39}

Expert consensus

Strength of consensus +++

Particularly in cases of extremely preterm birth, longitudinal uterine section may be appropriate in individual cases as it may be the most beneficial form of delivery for the infant.

\section{Consensus-based Recommendation 6.E40}

\begin{tabular}{l|l} 
Expert consensus & Strength of consensus +++
\end{tabular}

Because of the increased risk of uterine rupture, women who have had a previous longitudinal c-section must be delivered by primary repeat c-section in all subsequent births.

$[65,66]$

\subsubsection{Vaginal operative delivery}

\section{Consensus-based Recommendation 6.E41}

Expert consensus

Strength of consensus ++

Because of the increased risk of intraventricular hemorrhage, fetuses under the age of $34+0$ weeks of gestation should not be delivered by vacuum extraction.

[67]

\subsubsection{Fetal blood gas analysis}

Consensus-based Recommendation 6.E42

Expert consensus

Strength of consensus +++

Fetal blood gas analysis should not be carried out for fetuses under the age of $34+0$ weeks of gestation because of the potential risk of injury.

\subsubsection{Antibiotic prophylaxis for group B streptococcus}

Consensus-based Recommendation 6.E43

Expert consensus

Strength of consensus +++

If the GBS status of a case of preterm birth is positive or unknown, antibiotic prophylaxis must be administered during delivery.

[68]

\subsubsection{Cooperation with the Neonatology Department}

\section{Consensus-based Recommendation 6.E38}

\begin{tabular}{l|l} 
Expert consensus & Strength of consensus ++
\end{tabular}

Depending on the sonographically estimated fetal weight and other factors, delivery by cesarean section should be considered to reduce neonatal morbidity and mortality if the fetus is aged $<\mathrm{GW} 36+0$ and in breech presentation.

[64]

\section{Consensus-based Recommendation 6.E44}

\begin{tabular}{l|l} 
Expert consensus & Strength of consensus ++
\end{tabular}

A pediatrician/neonatologist must be involved early on in the treatment and counselling of women with an imminent risk of preterm birth.

[69-71] 
The treating pediatrician must be given all information about the pregnant woman which may be important for the initial medical treatment and therapy of the preterm infant. Such information includes any medication taken, HBsAg status, blood group, CMV antibody status (up to the 32nd week of gestation), findings from any prenatal diagnostic workups, and results of microbiological screening of the pregnant woman at imminent risk of preterm birth for GBS, MRSA, MRGN as well as the results of any repeat screenings if pregnancy is prolonged.

\section{Consensus-based Recommendation 6.E45 \\ Expert consensus \\ Strength of consensus ++}

When an infant is born preterm (<GW $35+0)$, a physician with experience in neonatology must be present to directly oversee the care of the newborn infant. If there is an imminent risk of preterm birth before GW $32+0$ and/or the estimated weight/birthweight is $<1500 \mathrm{~g}$, a specialist physician with a subspecialization in neonatology must be on call.

[72]

\subsubsection{Terminal care}

\section{Consensus-based Recommendation 6.E46}

\begin{tabular}{l|l} 
Expert consensus & Strength of consensus +++
\end{tabular}

Specially trained staff must be called in to offer palliative and terminal care to deceased or dying newborns and their family in the perinatal phase. Terminal care is included in perinatology training. According to the tenets of the German Medical Association, offering terminal care with dignity is a key medical duty for physicians which they cannot delegate.

$[73-75]$

7

\section{Special Aspects Relating to Twin and Multiple} Pregnancies

7.1 Epidemiology and etiology

\begin{tabular}{|l|l|}
\hline Consensus-based Statement 7.528 \\
\hline Expert consensus & Strength of consensus +++ \\
\hline $\begin{array}{l}\text { Women carrying a multiple pregnancy have a significantly higher risk } \\
\text { of preterm birth. }\end{array}$ \\
\hline$[76,77]$ \\
\hline
\end{tabular}

\subsection{Prevention}

\subsubsection{Progesterone}

\begin{tabular}{l|l} 
Consensus-based Recommendation 7.E47 \\
\hline Expert consensus & Strength of consensus +++
\end{tabular}

Women must not be given progesterone to prevent preterm birth only because they are carrying twins.

$[78,79]$

\section{Consensus-based Recommendation 7.E48}

\section{Expert consensus}

Strength of consensus +++

Women carrying a twin pregnancy who have a cervical length of $\leq 25 \mathrm{~mm}$ before GW $24+0$ as measured by transvaginal ultrasound should receive a daily dose of 200-400 mg progesterone applied intravaginally until GW $36+6$.

An individual patient data meta-analysis (IPDMA) of six studies [79-84] carried out by Romero et al. in 2017, which compared the application of vaginal progesterone with placebo or no treatment in 303 asymptomatic women with twin pregnancy and a cervical length of $\leq 25 \mathrm{~mm}$ in the second trimester, found a significant reduction in preterm births before the 33rd week of gestation (31.4 vs. $43.1 \%$; RR 0.69 [95\% Cl: 0.51-0.93]) and improved neonatal outcomes (e.g., lower neonatal mortality rate [RR 0.53; $95 \% \mathrm{Cl} 0.35-0.81]$, lower incidence of respiratory distress syndrome [RR 0.70; $95 \% \mathrm{Cl}$ : 0.56-0.89], fewer neonates with a birthweight < $1500 \mathrm{~g}$ [RR 0.53; 95\% Cl: 0.35-0.80]) [85].

\subsubsection{Cerclage}

\section{Consensus-based Recommendation 7.E49}

\section{Expert consensus}

Strength of consensus +++

Primary or secondary cerclage should not be placed in women with twin pregnancies.

The first meta-analysis of three prospective randomized studies found a significantly higher preterm birth rate before the 35th week of gestation for women carrying a twin pregnancy after placement of a primary or secondary cerclage (76 vs. $36 \%$; RR 2.15, 95\% Cl: 1.15-4.01) [86-89]. Another meta-analysis has since been carried out which additionally took individual patient data into account [90]. This meta-analysis found that placement of a cerclage had no negative effect on the preterm birth rate or perinatal morbidity, at least for patients with a short cervix, before the 24th week of gestation.

\subsubsection{Cervical pessary for shortened cervical length}

\section{Consensus-based Recommendation 7.E50}

Expert consensus

Strength of consensus +++

A cervical pessary can be placed in individual cases with twin pregnancy and a cervical length of $\leq 25 \mathrm{~mm}$ before GW $24+0$ as measured by transvaginal sonography.

Given the fact that prospective randomized studies have reported both positive [91-93] and negative [94,95] data, the decision whether or not to carry out this procedure must be made on a case-by-case basis. 


\subsubsection{Cervical pessary after preterm labor and shortened cervical length}

\begin{tabular}{l} 
Consensus-based Statement 7.S29 \\
\hline Expert consensus \\
\hline There is some evidence from a prospective randomized study that \\
placement of a cervical pessary in cases with twin pregnancy previously \\
treated for preterm labor and with a shortened cervical length as measured \\
by transvaginal ultrasound $(<20 \mathrm{~mm}$ between GW $24+0$ and GW $29+6$; \\
$<10 \mathrm{~mm}$ between GW $30+0$ and GW $33+6)$ can reduce the rate of \\
preterm births.
\end{tabular}

In a prospective randomized study which included 132 women with twin pregnancy between GW $24+0$ and GW $33+6$ [96], patients who were found to have a shortened cervical length ( $\leq 20 \mathrm{~mm}$ between GW $24+0$ and GW $29+6$; $\leq 10 \mathrm{~mm}$ between GW $30+0$ and GW $33+6) 48$ h after treatment for preterm labor either underwent placement of a cervical pessary or received the usual standard care. The primary study outcome - i.e., the preterm rate before the 34th week of gestation - was significantly lower in the intervention goup (16.4 vs. $32.3 \%$; RR 0.51 [ $95 \% \mathrm{Cl}$ : 0.27-0.97]) as was the number of readmitted patients after treatment for preterm labor (5.6 vs. 21.5\%; RR 0.28 [95\% Cl: $0.10-$ $0.80])$. Moreover, placement of a cervical pessary significantly reduced the prevalence of necrotizing enterocolitis (0 vs. $4.6 \%$ ) and of neonatal sepsis ( 0 vs. $6.2 \%$ ).

\subsubsection{Emergency cerclage}

\begin{tabular}{l} 
Consensus-based Recommendation 7.E51 \\
\hline Expert consensus \\
If the cervix has opened more than $1 \mathrm{~cm}$ before GW $24+0$, emergency \\
cerclage may be carried out even in women with a twin pregnancy with \\
the aim of significantly prolonging the pregnancy.
\end{tabular}

As has already been established for women with singleton pregnancies, cohort studies have shown that a twin pregnancy can also be prolonged if an emergency cerclage is placed in women with an opened cervix before GW $24+0$ [97-100].

\section{$8 \quad$ Preterm Premature Rupture of Membranes (PPROM) \\ 8.1 Prevalence and Etiology}

\section{Consensus-based Statement 8.530}

\begin{tabular}{l|l} 
Expert consensus & Strength of consensus +++
\end{tabular}

Around $3 \%$ of all pregnant women are affected by preterm premature rupture of membranes (rupture of membranes before GW $37+0$ ): $0.5 \%$ before the 27 th week of gestation, $1 \%$ between 27 and 34 weeks of gestation and $1 \%$ between the 34 th and the 37 th week of gestation.

[101]

\subsection{Risk factors}

Consensus-based Statement 8.531

Expert consensus

Strength of consensus +++

A previous history of PPROM is a significant risk factor for preterm premature rupture of membranes. The additional risk factors are similar to those for spontaneous preterm birth.

$[102,103]$

8.3 Diagnostic workup

Consensus-based Recommendation 8.E52

Expert consensus

Strength of consensus +++

In most cases, PPROM can be diagnosed by speculum examination. If there is still some uncertainty, then biochemical tests must be carried out.

$[104,105]$

\section{Consensus-based Recommendation 8.E53}

\begin{tabular}{l|l} 
Expert consensus & Strength of consensus +++
\end{tabular}

A digital examination must be avoided in patients with PPROM.

When examining patients with PPROM, a digital examination must be avoided where possible, because digital examinations increase the risk of ascending infection and significantly reduce the latency period to delivery $[106,107]$.

\subsection{Latency period}

\section{Consensus-based Statement 8.S32}

\begin{tabular}{l|l} 
Expert consensus & Strength of consensus +++
\end{tabular}

More than $50 \%$ of all patients with PPROM are delivered within one week.

$[108,109]$

\subsection{Maternal and fetal risks}

\section{Consensus-based Statement 8.533}

Expert consensus

Strength of consensus +++

Patients with PPROM have a risk of clinical infection. Additional risks include placental abruption and umbilical cord prolapse.

$[110-115]$ 


\section{Consensus-based Statement 8.534}

Expert consensus

\section{Strength of consensus +++}

Internationally, the term "Triple I" has superseded the term chorioamnionitis to differentiate maternal fever from infection or inflammation or both.
- Table 6 Classification of maternal fever and Triple I*.

\begin{tabular}{|c|c|}
\hline & Definition \\
\hline $\begin{array}{l}\text { Maternal } \\
\text { fever }\end{array}$ & $\begin{array}{l}\text { Maternal fever is present when the orally measured } \\
\text { temperature exceeds } 39.0^{\circ} \mathrm{C} \text {. } \\
\text { If the orally measured temperature is between } 38.0 \text { and } \\
38.9^{\circ} \mathrm{C} \text {, the temperature should be measured again after } \\
30 \text { minutes. If the temperature again exceeds } 38.0^{\circ} \mathrm{C} \text {, } \\
\text { then maternal fever is present. }\end{array}$ \\
\hline $\begin{array}{l}\text { Suspicious } \\
\text { for Triple I }\end{array}$ & $\begin{array}{l}\text { Maternal fever of unclear origin together with at least } \\
\text { one of the following criteria: } \\
\text { - fetal tachycardia of more than } 160 \text { beats/min for } \\
>10 \text { min } \\
\text { - maternal leukocytes }>15000 \mu / \text { without the } \\
\text { administration of corticosteroids } \\
\text { - purulent discharge from the cervix }\end{array}$ \\
\hline $\begin{array}{l}\text { Confirmed } \\
\text { Triple I }\end{array}$ & $\begin{array}{l}\text { Suspicion of Triple I and objective findings of infection, } \\
\text { such as: } \\
\text { positive Gram staining of amniotic fluid }{ }^{* *} \text {, low glucose } \\
\text { concentrations }(<14 \mathrm{mg} / \mathrm{dll}) \text {, increased number of } \\
\text { leukocytes }\left(>30 \text { cells } / \mathrm{mm}^{3}\right) \text {, positive bacterial culture } \\
\text { or } \\
\text { histopathological findings*** of inflammation or infection } \\
\text { of both of the placenta, the amniotic membranes or the } \\
\text { umbilical cord (funisitis) }\end{array}$ \\
\hline
\end{tabular}

* Triple I: inflammation or infection or both; ${ }^{* *}$ amniotic fluid obtained by amniocentesis; ${ }^{* * *}$ postpartum histopathology of the placenta [116].

Maternal and fetal risks associated with Triple I

\section{Consensus-based Statement 8.535}

\begin{tabular}{l|l} 
Expert consensus & Strength of consensus +++
\end{tabular}

In addition to sepsis, maternal risks associated with Triple I include uterine dysfunction with the risk of failure to progress in labor and uterine atony post partum. In cases where delivery was by cesarean section, risks include wound infection, endomyometritis, thrombophlebitis and pelvic abscess formation.

$[117-122]$

\section{Consensus-based Recommendation 8.E54}

Expert consensus

Strength of consensus +++

If PPROM occurs before the fetus has achieved viability, the risk of maternal sepsis, fetal pulmonary hypoplasia and fetal skeletal deformities must be discussed with the future parents.

$[125-127]$

\section{Consensus-based Recommendation 8.E55}

\begin{tabular}{l|l} 
Expert consensus & Strength of consensus +++
\end{tabular}

Antibiotic therapy may be considered in patients with PPROM before the fetus has achieved viability.

As almost all studies on antibiotic therapy in cases with rupture of membranes only recruited patients after the $24+0$ week of gestation, there are no reliable data on the administration of antibiotics before the fetus has achieved viability. But the risk that the patient may develop sepsis due to ascending infection suggests that antibiotic therapy is advisable [128]. The same regimen as the one described for PPROM between (GW $22+0$ ) GW $24+0$ and GW $33+6 \mathrm{GW}$ can be used.

\section{Consensus-based Recommendation 8.E56}

Expert consensus

\section{Strength of consensus +++}

Antenatal steroid administration, tocolysis and neuroprotection with magnesium must not be carried out in cases with PPROM before the fetus has achieved viability.

\subsection{Clinical management of PPROM between} $(G W 22+0)$ GW $24+0$ and GW $33+6$

\section{Consensus-based Recommendation 8.E57}

\section{Expert consensus}

Strength of consensus +++

Recommendation: Between GW $22+0$ and GW $23+6$ the further course of action should be agreed upon with the parents in accordance with the German-language guideline "Frühgeborene an der Grenze der Lebensfähigkeit 024-019” [Preterm infants at the limits of viability].

\subsubsection{Expectant management}

\section{Consensus-based Statement 8.S36}

\begin{tabular}{l|l} 
Expert consensus & Strength of consensus +++
\end{tabular}

The fetus may develop inflammatory response syndrome as part of Triple I. Affected infants have a higher risk of sepsis post partum.

$[123,124]$

\section{Consensus-based Recommendation 8.E58}

\begin{tabular}{l|l} 
Expert consensus & Strength of consensus ++
\end{tabular}

If PPROM occurs between GW $24+0$ and GW $33+6$ or between GW $22+0$ and GW $23+6$ if maximum therapy is requested, expectant management must be considered first if there is no immediate risk to mother or child. 
If PPROM occurs between GW $24+0$ and GW $33+6$ or between GW $22+0$ and GW $23+6$ if maximum therapy is requested, the risks of ascending infection must be weighed against the neonatal risks which can result from preterm birth ( $\bullet$ Table 7 ). An ascending infection with chorioamnionitis, preterm placental abruption, pathological CTG, or umbilical cord prolapse are indications for immediate delivery of the fetus. Otherwise expectant management is currently the international standard of care [129].

- Table 7 Planned delivery vs. expectant management of PPROM between the 24th and the 37 th week of gestation.

\begin{tabular}{|l|l|l|}
\hline $\begin{array}{l}\text { Planned delivery vs. expectant } \\
\text { management }\end{array}$ & RR & $\mathbf{9 5} \mathbf{C l}$ \\
\hline Neonatal sepsis & 0.93 & $0.66-1.30$ \\
\hline Neonatal infection (positive blood culture) & 1.24 & $0.70-2.21$ \\
\hline RDS & 1.26 & $1.05-1.53$ \\
\hline Cesarean section & 1.26 & $1.11-1.44$ \\
\hline Perinatal mortality & 1.76 & $0.89-3.50$ \\
\hline Intrauterine fetal death & 0.45 & $0.13-1.57$ \\
\hline Neonatal mortality & 2.55 & $1.17-5.56$ \\
\hline Mechanical ventilation required & 1.27 & $1.02-1.58$ \\
\hline Transfer to neonatal intensive care unit & 1.16 & $1.08-1.24$ \\
\hline Chorioamnionitis & 0.50 & $0.26-0.95$ \\
\hline Endomyometritis & 1.61 & $1.00-2.59$ \\
\hline Induction of labor & 2.18 & $2.01-2.36$ \\
\hline [130] & & \\
\hline
\end{tabular}

\subsubsection{Administration of antenatal steroids}

\section{Consensus-based Recommendation 8.559}

Expert consensus

\section{Strength of consensus +++}

Patients with PPROM between GW $24+0$ and GW $33+6$ or between GW 22 and GW $23+6$, if maximum therapy is requested, must be given antenatal steroids consisting of $2 \times 12 \mathrm{mg}$ betamethasone administered IM at an interval of $24 \mathrm{~h}$ (alternatively dexamethasone, $4 \times 6 \mathrm{mg}$ every $12 \mathrm{~h}$ ).

\subsubsection{Administration of antibiotics}

\section{Consensus-based Recommendation 8.E60}

\section{Expert consensus}

Strength of consensus ++

Patients with PPROM between GW $24+0$ and GW $33+6$ or between GW 22 and GW $23+6$, if maximum therapy is requested, must be given antibiotic therapy.

[131]

\section{Consensus-based Recommendation 8.E61}

\section{Expert consensus}

Strength of consensus +++

The data are not sufficient to permit any recommendations to be made about specific therapy regimens. One option is IV administration of ampicillin over 2 days followed by 5 days of oral amoxicillin and a single oral dose of azithromycin at the start. Amoxicillin must not be combined with clavulanic acid.

$[108,129,131]$

\subsubsection{Tocolysis}

\begin{tabular}{|l|}
\hline Consensus-based Statement 8.537 \\
\hline Expert consensus
\end{tabular}

Tocolysis is not associated with any significant improvement in perinatal morbidity and mortality rates in cases with PPROM.

[132]

\subsubsection{Neuroprotection}

See 6.8.1.

\subsubsection{Maternal and fetal monitoring}

Consensus-based Recommendation 8.E62

\section{Expert consensus}

Strength of consensus +++

Patients with PPROM must be carefully monitored for Triple I. Clinical signs include maternal fever plus one of the following: fetal tachycardia (> 160 beats/min) or leukocytes $>15000 / \mu$ l or purulent discharge from the cervix.

Pregnant women with preterm premature rupture of membranes should be routinely examined for signs of infection. In addition to the above-mentioned clinical parameters, such signs also include symptoms such as painful uterus, uterine contractions, maternal blood pressure and heart rate [116]. Blood count and CRP must additionally be monitored at least once a day. However, the benefit of daily laboratory tests is disputed [133]. Kunze et al. reported an AUC of just 0.66 for a combination of maternal fever, CRP and leukocytes to predict FIRS [134]. Musilova et al. reported a sensitivity of $47 \%$, specificity of $96 \%$, positive predictive value of $42 \%$ and negative predictive value of $96 \%$ for a CRP value of $17.5 \mathrm{mg} / \mathrm{l}$ in maternal serum to predict intraamniotic infection or inflammation [135].

Daily CTG monitoring of patients with PPROM is standard clinical practice. But currently there is no fetal monitoring method which can reliably detect intrauterine inflammation or infection. Neither CTG nor the use of a biophysical profile (CTG plus fetal breathing movements and other fetal movements, fetal tone and amniotic fluid volume assessment) are suitable predictors for intrauterine infection (CTG: sensitivity 39\%; biophysical profile: $25 \%)$ [115].

Regular monitoring of amniotic fluid volumes is similarly of little benefit. While a reduction in amniotic fluid volume increases 
the risk of umbilical cord compression and demonstrably reduces the time to the start of labor, its predictive value for a negative outcome is low [136]. The use of Doppler sonography has no proven benefits for premature rupture of membranes [137].

\section{Consensus-based Statement 8.538}

\begin{tabular}{l|l} 
Expert consensus & Strength of consensus ++
\end{tabular}

The use of amniocentesis to diagnose Triple I is only useful in exceptional cases, e.g. when the source of maternal infection is not clear.

[138]

\section{Consensus-based Statement 8.539}

\begin{tabular}{l|l} 
Expert consensus & Strength of consensus +++
\end{tabular}

The prediction of Triple I based on biochemical parameters measured in vaginal secretions is not useful according to current knowledge.

$[134,139]$

\subsubsection{Amniotic infusion}

\begin{tabular}{l|l|l|}
\hline Consensus-based Statement 8.540 \\
\hline Expert consensus & Strength of consensus +++
\end{tabular}

The value of amniotic infusion in cases of PPROM cannot be sufficiently evaluated based on the data currently available.

[140]

\subsubsection{Antibiotic prophylaxis for Group B streptococcus}

See the recommendations on GBS prophylaxis.

\subsubsection{Delivery}

\section{Consensus-based Recommendation 8.E63}

\begin{tabular}{l|l} 
Expert consensus & Strength of consensus +++
\end{tabular}

Patients with PPROM between GW $24+0$ and GW $33+6$ or between GW 22 and GW $23+6$, if maximum therapy is requested, can be delivered from GW $34+0$ onwards. Indications for immediate delivery are Triple I (suspicion of Triple I or confirmed), premature placental abruption, pathological CTG or high risk, or umbilical cord prolapse.

$[129,130]$

\section{Consensus-based Recommendation 6.E65}

Expert consensus

Strength of consensus +++

If preterm premature rupture of membranes occurs between GW $34+0$ and GW $36+6$, expectant management may be considered as an alternative to prompt delivery, with the aim of prolonging the pregnancy until GW $37+0$. This does not apply if Group B streptococcus is detected in vaginal secretions.

A total of 1839 women between GW $34+0$ and GW $36+6$ who had preterm premature rupture of membranes (PPROM) were recruited into the PPROMT trial between 2004 and 2013 [141]. Immediate induction of labor was compared with expectant management. In the study group, $21 \%$ of infants were born after the 37th week of gestation to women managed expectantly compared to only $3 \%$ in the control group. The prevalence of neonatal sepsis was the same for both groups, however respiratory distress syndrome (RDS) occurred significantly less often after expectant management. In this group, the birthweight of the children was also significantly higher and the stay in the neonatal intensive care unit or in hospital was shorter. However, as expected, uterine bleeding before or during birth occurred more often in the mothers of these children as did peripartum fever. The c-section rate was significantly lower compared to the group who had induction of labor [141].

The results of the PPROMT trial were supported by the findings of the PPROMEXIL and PPROMEXIL-2 trials [142,143]. But if Group B streptococcus colonization was diagnosed, the prevalence of early onset sepsis was significantly higher among affected neonates (15.2 vs. $1.8 \%$; $p=0.04$ ) [144].

According to a meta-analysis of this issue which included 12 studies, expectant management was still not found to be associated with an increased prevalence of neonatal sepsis. Following immediate induction of labor, the rates for RDS, neonatal mortality, required ventilation, endomyometritis and cesarean section were significantly higher while the incidence of chorioamnionitis was lower [130]. A patient-level meta-analysis came to similar conclusions [145].

\section{Consensus-based Recommendation 8.E66}

Clinical monitoring and antibiotic therapy in cases with PPROM between GW $34+0$ and GW $36+6$ must follow the recommendations for $(G W 22+0)$ GW $24+0-G W 33+6$. Antenatal steroids, tocolysis or neuroprotection with magnesium must not be administered.
Consensus-based Recommendation 8.E64

\begin{tabular}{l|l} 
Expert consensus & Strength of consensus +++
\end{tabular}

Patients with Triple I (suspicion or confirmed) must be given antibiotics and their infant must be delivered. 


\section{$9 \quad$ Psychosomatic Care and Supportive Therapy}

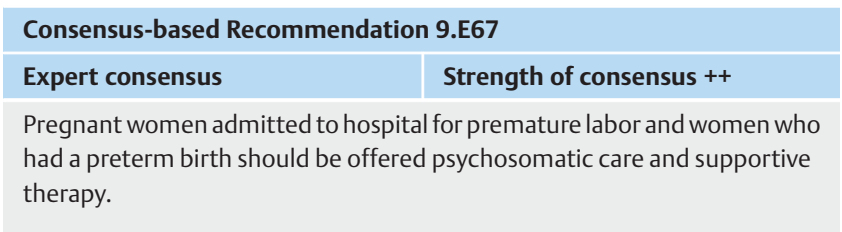

In addition to worries about the health consequences of a preterm birth (which are difficult to estimate), therapeutic measures, which can include immobilization, medication to stop contractions and the administration of corticosteroids, may be experienced as stressful. If there are additional stresses (a previous experience of loss, prior mental health problems, partnership difficulties, etc.), then the incidence of anxiety and depression is higher [146-148]. Particularly for large families, admission of the mother to hospital represents substantial organizational pressures for the family.

There are a number of psychometric tests which are used to detect psychological and social stress factors, such as HADS, the Babylotse Plus screening questionnaires, etc. [149].

Affected couples should be offered acute psychological crisis intervention, followed by offers of supportive talks and psychotherapy where necessary. This also supports parent-child bonding.

The support offered by self-help groups such as the German federal association "Das Frühgeborene Kind" [The Preterm Infant] [150] can help affected parents, and parents should be informed about such options.

Affected families should be actively offered options in the context of the Frühe Hilfe network. This is a German network that creates local and regional support systems offering coordinated services to parents and children, which aims to improve familial and social development opportunities for children and parents, both in the early stages and over the long term [151].

The "Babylotse" program, which arranges the transfer of families from the regular healthcare system to the Frühe Hilfe network and other social care systems has proven to be particularly useful. The core aspect of this program is the role it plays in guiding parents to find and use the most suitable options from among the numerous local choices available.

All of these measures are services which provide compassionate support to the patient and her family and which are offered in addition to the care provided by the attending midwife.

\section{Conflict of Interest}

The conflict of interest statements of all the authors are available in the long version of the guideline.

\section{References}

[1] Fischer T, Mörtl M, Reif P et al. Statement by the OEGGG with Review of the Literature on the Mode of Delivery of Premature Infants at the Limit of Viability. Geburtsh Frauenheilk 2018; 78: 1212-1216

[2] Gyamfi-Bannerman C, Thom EA, Blackwell SC et al.; NICHD Maternal-Fetal Medicine Units Network. Antenatal betamethasone for women at risk for late preterm delivery. N Engl J Med 2016; 374: 1311-1320

[3] SGGG. Lungenreifungsinduktion bei drohender Frühgeburt. Online: https://www.sggg.ch/fileadmin/user_upload/56_ Lungenreifungsinduktion_bei_drohender_Fruehgeburt.pdf; last access: 28.04.2019

[4] Swiss-Paediatrics. Perinatale Betreuung an der Grenze der Lebensfähigkeit zwischen 22 und 26 vollendeten Schwangerschaftswochen. Online: http://www.swiss-paediatrics.org/sites/default/files/paediatrica/vol23/ n1/pdf/10-12_0.pdf; last access: 28.04.2019

[5] SGGG. Expertenbrief Tokolyse. Online: https://www.sggg.ch/fileadmin/ user_upload/Dokumente/3_Fachinformationen/1_Expertenbriefe/De/ 41_Tokolyse_2013.pdf; last access: 28.04.2019

[6] Sosa CG, Althabe F, Belizán JM et al. Bed rest in singleton pregnancies for preventing preterm birth. Cochrane Database Syst Rev 2015; (3): CD003581

[7] Hobel C], Ross MG, Bemis RL et al. The West Los Angeles Preterm Birth Prevention Project. I. Program impact on high-risk women. Am J Obstet Gynecol 1994; 170: 54-62

[8] Elliott JP, Miller HS, Coleman S et al. A randomized multicenter study to determine the efficacy of activity restriction for preterm labor management in patients testing negative for fetal fibronectin. J Perinatol 2005; 25: 626-630

[9] Bigelow CA, Factor SH, Miller M et al. Pilot Randomized Controlled Trial to Evaluate the Impact of Bed Rest on Maternal and Fetal Outcomes in Women with Preterm Premature Rupture of the Membranes. Am J Perinatol 2016; 33: 356-363

[10] da Silva Lopes K, Takemoto Y, Ota E et al. Bed rest with and without hospitalisation in multiple pregnancy for improving perinatal outcomes. Cochrane Database Syst Rev 2017; (3): CD012031

[11] Haas DM, Imperiale TF, Kirkpatrick PR et al. Tocolytic therapy: A metaanalysis and decision analysis. Obstet Gynecol 2009; 113: 585-594

[12] Haas DM, Caldwell DM, Kirkpatrick P et al. Tocolytic therapy for preterm delivery: systematic review and network meta-analysis. BMJ 2012; 345: e6226

[13] de Heus R, Mol BW, Erwich JJ et al. Adverse drug reactions to tocolytic treatment for preterm labour: prospective cohort study. BM] 2009; 338: b744

[14] Vogel JP, Oladapo OT, Manu A et al. New WHO recommendations to improve the outcomes of preterm birth. Lancet Glob Health 2015; 3: e589e590

[15] Crowther CA, Brown J, McKinlay Cl et al. Magnesium sulphate for preventing preterm birth in threatened preterm labour. Cochrane Database Syst Rev 2014; (8): CD001060

[16] [Anonymous]. Practice Bulletin No. 171: Management of Preterm Labor. Obstet Gynecol 2016; 128: e155-e164

[17] Sentilhes L, Senat MV, Ancel PY et al. Prevention of spontaneous preterm birth: Guidelines for clinical practice from the French College of Gynaecologists and Obstetricians (CNGOF). Eur J Obstet Gynecol Reprod Biol 2017; 210: 217-224

[18] Di Renzo GC, Cabero Roura L, Facchinetti F et al. Preterm Labor and Birth Management: Recommendations from the European Association of Perinatal Medicine. J Matern Fetal Neonatal Med 2017; 30: 2011-2030

[19] Vogel JP, Nardin JM, Dowswell T et al. Combination of tocolytic agents for inhibiting preterm labour. Cochrane Database Syst Rev 2014; (7): CD006169 
[20] Martinez de Tejada B, Karolinski A, Ocampo MC et al. Prevention of preterm delivery with vaginal progesterone in women with preterm labour (4P): randomised double-blind placebo-controlled trial. BJOG 2015; 122 : 80-91

[21] Miyazaki C, Moreno Garcia R, Ota E et al. Tocolysis for inhibiting preterm birth in extremely preterm birth, multiple gestations and in growth-restricted fetuses: a systematic review and meta-analysis. Reprod Health 2016; $13: 4$

[22] Dodd JM, Crowther CA, Middleton P. Oral betamimetics for maintenance therapy after threatened preterm labour. Cochrane Database Syst Rev 2012; (12): CD003927

[23] Naik Gaunekar N, Raman P, Bain E et al. Maintenance therapy with calcium channel blockers for preventing preterm birth after threatened preterm labour. Cochrane Database Syst Rev 2013; (10): CD004071

[24] van Vliet E, Dijkema GH, Schuit E et al. Nifedipine maintenance tocolysis and perinatal outcome: an individual participant data meta-analysis. BJOG 2016; 123: 1753-1760

[25] Han S, Crowther CA, Moore V. Magnesium maintenance therapy for preventing preterm birth after threatened preterm labour. Cochrane Database Syst Rev 2013; (5): CD000940

[26] Wood S, Rabi Y, Tang S et al. Progesterone in women with arrested premature labor, a report of a randomised clinical trial and updated metaanalysis. BMC Pregnancy Childbirth 2017; 17: 258

[27] Pratcorona L, Goya M, Merced C et al. Cervical pessary to reduce preterm birth $<34$ weeks of gestation after an episode of preterm labor and a short cervix: a randomized controlled trial. Am J Obstet Gynecol 2018; 219: 99.e16

[28] Hermans FJR, Schuit E, Bekker MN et al. Cervical Pessary After Arrested Preterm Labor: A Randomized Controlled Trial. Obstet Gynecol 2018; 132: 741-749

[29] King J, Flenady V. Prophylactic antibiotics for inhibiting preterm labour with intact membranes. Cochrane Database Syst Rev 2002; (4): CD000246

[30] Simcox R, Sin WT, Seed PT et al. Prophylactic antibiotics for the prevention of preterm birth in women at risk: a meta-analysis. Aust N Z J Obstet Gynaecol 2007; 47: 368-377

[31] Roberts D, Brown J, Medley N et al. Antenatal corticosteroids for accelerating fetal lung maturation for women at risk of preterm birth. Cochrane Database Syst Rev 2017; 3: CD004454

[32] Deshmukh M, Patole S. Antenatal corticosteroids for neonates born before 25 Weeks-A systematic review and meta-analysis. PLoS One 2017; 12: e0176090

[33] Zephyrin LC, Hong KN, Wapner RJ et al. Gestational age-specific risks vs. benefits of multicourse antenatal corticosteroids for preterm labor. Am J Obstet Gynecol 2013; 209: 330.e337

[34] Norman M, Piedvache A, Borch K et al. Association of Short Antenatal Corticosteroid Administration-to-Birth Intervals With Survival and Morbidity Among Very Preterm Infants: Results from the EPICE Cohort. JAMA Pediatr 2017; 171: 678-686

[35] Liebowitz M, Clyman RI. Antenatal Betamethasone: A Prolonged Time Interval from Administration to Delivery Is Associated with an Increased Incidence of Severe Intraventricular Hemorrhage in Infants Born before 28 Weeks Gestation. J Pediatr 2016; 177: 114-120.e1

[36] Norberg H, Kowalski J, Marsal K et al. Timing of antenatal corticosteroid administration and survival in extremely preterm infants: a national population-based cohort study. BJOG 2017; 124: 1567-1574

[37] van Baaren G], Vis JY, Wilms FF et al. Predictive value of cervical length measurement and fibronectin testing in threatened preterm labor. Obstet Gynecol 2014; 123: 1185-1192

[38] Melchor JC, Khalil A, Wing D et al. Prediction of preterm delivery in symptomatic women using PAMG-1, fetal fibronectin and phIGFBP-1 tests: systematic review and meta-analysis. Ultrasound Obstet Gynecol 2018; 52: 442-451
[39] Khandelwal M, Chang E, Hansen C et al. Betamethasone dosing interval: 12 or 24 hours apart? A randomized, noninferiority open trial. Am J Obstet Gynecol 2012; 206: 201.e1-201.e11

[40] Stutchfield P, Whitaker R, Russell I. Antenatal betamethasone and incidence of neonatal respiratory distress after elective caesarean section: pragmatic randomised trial. BMJ 2005; 331: 662

[41] Stutchfield PR, Whitaker R, Gliddon AE et al. Behavioural, educationa and respiratory outcomes of antenatal betamethasone for term caesarean section (ASTECS trial). Arch Dis Child Fetal Neonatal Ed 2013; 98: F195-F200

[42] Ehsanipoor RM, Seligman NS, Saccone G et al. Physical Examination-Indicated Cerclage. Obstet Gynecol 2015; 126: 125-135

[43] Miller ES, Grobman WA, Fonseca L et al. Indomethacin and antibiotics in examination-indicated cerclage: a randomized controlled trial. Obstet Gynecol 2014; 123: 1311-1316

[44] Volpe J. Neurology of the Newborn. Philadelphia: W.B. Saunders Company; 1995

[45] Doyle LW, Crowther CA, Middleton P et al. Magnesium sulphate for women at risk of preterm birth for neuroprotection of the fetus. Cochrane Database Syst Rev 2009; (1): CD004661

[46] Crowther CA, Middleton PF, Voysey M et al. Assessing the neuroprotec tive benefits for babies of antenatal magnesium sulphate: An individual participant data meta-analysis. PLoS Med 2017; 14: e1002398

[47] Backes $\mathrm{CH}$, Rivera BK, Haque $U$ et al. Placental transfusion strategies in very preterm neonates: A systematic review and meta-analysis. Obstet Gynecol 2014; 124: 47-56

[48] Tarnow-Mordi W, Morris ], Kirby A et al. Delayed versus Immediate Cord Clamping in Preterm Infants. N Engl J Med 2017; 377: 2445-2455

[49] Fogarty M, Osborn DA, Askie L et al. Delayed vs. early umbilical cord clamping for preterm infants: a systematic review and meta-analysis. Am J Obstet Gynecol 2018; 218: 1-18

[50] Jonas HA, Khalid N, Schwartz SM. The relationship between Caesarean section and neonatal mortality in very-low-birthweight infants born in Washington State, USA. Paediatr Perinat Epidemiol 1999; 13: 170-189

[51] Lee HC, Gould JB. Survival rates and mode of delivery for vertex preterm neonates according to small- or appropriate-for-gestational-age status. Pediatrics 2006; 118: e1844

[52] Muhuri PK, Macdorman MF, Menacker F. Method of delivery and neonatal mortality among very low birth weight infants in the United States. Matern Child Health J 2006; 10: 47-53

[53] Malloy $\mathrm{MH}$. Impact of cesarean section on neonatal mortality rates among very preterm infants in the United States, 2000-2003. Pediatrics 2008; 122: 285-292

[54] Jonas HA, Lumley JM. The effect of mode of delivery on neonatal mortality in very low birthweight infants born in Victoria, Australia: Caesarean section is associated with increased survival in breech-presenting, but not vertex-presenting, infants. Paediatr Perinat Epidemiol 1997; 11: 181-199

[55] Riskin A, Riskin-Mashiah S, Lusky A et al. The relationship between delivery mode and mortality in very low birthweight singleton vertex-presenting infants. BJOG 2004; 111: 1365-1371

[56] Wylie BJ, Davidson LL, Batra M et al. Method of delivery and neonatal outcome in very low-birthweight vertex-presenting fetuses. Am J Obstet Gynecol 2008; 198: 4

[57] Ghi T, Maroni E, Arcangeli T et al. Mode of delivery in the preterm gestation and maternal and neonatal outcome. J Matern Fetal Neonatal Med 2010; 23: 1424-1428

[58] Durie DE, Sciscione AC, Hoffman MK et al. Mode of delivery and outcomes in very low-birth-weight infants in the vertex presentation. Am J Perinatol 2011; 28: 195-200 
[59] Reddy UM, Zhang J, Sun L et al. Neonatal mortality by attempted route of delivery in early preterm birth. Am J Obstet Gynecol 2012; 207: 117. e1-117.e8

[60] Barzilay E, Gadot Y, Koren G. Safety of vaginal delivery in very low birthweight vertex singletons: a meta-analysis. J Matern Fetal Neonatal Med 2016; 29: 3724-3729

[61] Humberg A, Hartel C, Paul P et al. Delivery mode and intraventricular hemorrhage risk in very-low-birth-weight infants: Observational data of the German Neonatal Network. Eur J Obstet Gynecol Reprod Biol 2017; 212: $144-149$

[62] Holzer I, Lehner R, Ristl R et al. Effect of delivery mode on neonatal outcome among preterm infants: an observational study. Wien Klin Wochenschr 2017; 129: 612-617

[63] Racusin DA, Antony KM, Haase J et al. Mode of Delivery in Premature Neonates: Does It Matter? AJP Rep 2016; 6: e251-e259

[64] Bergenhenegouwen L, Vlemmix F, Ensing S et al. Preterm breech presentation: A comparison of intended vaginal and intended cesarean delivery. Obstet Gynecol 2015; 126: 1223-1230

[65] Landon MB, Hauth JC, Leveno KJ et al. Maternal and perinatal outcomes associated with a trial of labor after prior cesarean delivery. N Engl J Med 2004; 351: 2581-2589

[66] Landon MB, Lynch CD. Optimal timing and mode of delivery after cesarean with previous classical incision or myomectomy: a review of the data. Semin Perinatol 2011; 35: 257-261

[67] Aberg K, Norman M, Ekeus C. Preterm birth by vacuum extraction and neonatal outcome: A population-based cohort study. BMC Pregnancy Childbirth 2014; 14: 42

[68] Franz A, Härtel C, Herting E für die Gesellschaft für Neonatologie und Pädiatrische Intensivmedizin (GNPI) (Federführung); Kehl S für die Deutsche Gesellschaft für Gynäkologie und Geburtshilfe (DGGG); Gille C für die Deutsche Gesellschaft für pädiatrische Infektiologie (DGPI); Doubek K für den Berufsverband der Frauenärzte BVF e. V.; Spellerberg B für die Deutsche Gesellschaft für Hygiene und Mikrobiologie (DGHM); Maier RF, Vetter K für die Deutsche Gesellschaft für Perinatale Medizin (DGPM); Eglin K für den Bundesverband „Das frühgeborene Kind“ e. V. (BVDfK). Sepsis bei Neugeborenen-frühe Form-durch Streptokokken der Gruppe B, Prophylaxe. Online: https://www.awmf.org/leitlinien/detail/II/024020.html; last access: 03.12.2018

[69] Simon A (Leiter der Arbeitsgruppe), Christoph J, Geffers C et al. Empfehlung zur Prävention nosokomialer Infektionen bei neonatologischen Intensivpflegepatienten mit einem Geburtsgewicht unter $1500 \mathrm{~g}$. Online: https://www.rki.de/DE/Content/Infekt/Krankenhaushygiene/ Kommission/Downloads/Neo_Rili.pdf?_blob=publicationFile; last access: 28.04.2019

[70] Simon A (federführender Autor). Ergänzende Empfehlung (2011) zur „Prävention nosokomialer Infektionen bei neonatologischen Intensivpflegepatienten mit einem Geburtsgewicht unter 1.500 g“ (2007). Online: https://www.rki.de/DE/Content/Infekt/EpidBull/Archiv/2012/ Ausgaben/02_12.pdf?_blob=publicationFile; last access: 28.04.2019

[71] Christoph J, Dame C, Eckmanns T et al. Praktische Umsetzung sowie krankenhaushygienische und infektionspräventive Konsequenzen des mikrobiellen Kolonisationsscreenings bei intensivmedizinisch behandelten Früh- und Neugeborenen. Online: https://www.rki.de/DE/Content/ Infekt/EpidBull/Archiv/2013/Ausgaben/42_13.pdf?_blob=publication File; last access: 28.04.2019

[72] Richtlinie Qualitätssicherungs-Richtlinie Früh- und Reifgeborene, Stand: Inkrafttreten 01.01.2018 des Gemeinsamen Bundesausschusses über Maßnahmen zur Qualitätssicherung der Versorgung von Früh- und Reifgeborenen gemäß § 136 Absatz 1 Nummer 2 SGBV in Verbindung mit $\S 92$ Abs. 1 Satz 2 Nr. 13 SGB V. Online: https://www.g-ba.de/ downloads/62-492-1487/QFR-RL_2017-10-19_iK-2018-01-01.pdf; last access: 28.04 .2019
[73] Destatis. Todesursachen. Online: https://www.destatis.de/DE/Zahlen Fakten/GesellschaftStaat/Gesundheit/Todesursachen/Todesursachen. html; last access: 28.04.2019

[74] Bundesverband „Das frühgeborene Kind“ e.V. Leitsätze für Palliativversorgung und Trauerbegleitung in der Peri- und Neonatologie. Online: https://www.fruehgeborene.de/fuer-fachleute/palliativversorgung-undtrauerbegleitung; last access: 28.04.2019

[75] Grundsätze der Bundesärztekammer zur ärztlichen Sterbebegleitung. Deutsches Ärzteblatt: Ausgabe A, Praxis-Ausgabe: niedergelassene Ärzte 2011; 108: Heft 7: A346-A348. Online: https://www.bundesaerzte kammer.de/fileadmin/user_upload/downloads/Sterbebegleitung 17022011.pdf; last access: 28.04.2019

[76] IQTIG. Bundesauswertung zum Erfassungsjahr 2017 - Geburtshilfe Qualitätsindikatoren. Online: https://iqtig.org/downloads/auswertung/ 2017/16n1gebh/QSKH_16n1-GEBH_2017_BUAW_V02_2018-08-01. pdf; last access: 28.04.2019

[77] AQUA-Institut. 16/1 - Geburtshilfe Qualitätsindikatoren. Online: https:// sqg.de/downloads/Bundesauswertungen/2014/bu_Gesamt_16N1GEBH_2014.pdf; last access: 28.04.2019

[78] Dodd JM, Grivell RM, OBrien CM et al. Prenatal administration of progestogens for preventing spontaneous preterm birth in women with a multiple pregnancy. Cochrane Database Syst Rev 2017; (10): CD012024

[79] Serra V, Perales A, Meseguer ] et al. Increased doses of vaginal progesterone for the prevention of preterm birth in twin pregnancies: a randomised controlled double-blind multicentre trial. BJOG 2013; 120: 50-57

[80] Fonseca EB, Celik E, Parra M et al. Progesterone and the risk of preterm birth among women with a short cervix. N Engl J Med 2007; 357: 462469

[81] Cetingoz E, Cam C, Sakalli M et al. Progesterone effects on preterm birth in high-risk pregnancies: A randomized placebo-controlled trial. Arch Gynecol Obstet 2011; 283: 423-429

[82] Brizot ML, Hernandez W, Liao AW et al. Vaginal progesterone for the prevention of preterm birth in twin gestations: a randomized placebo-controlled double-blind study. Am J Obstet Gynecol 2015; 213: 82.e1-82.e9

[83] Elrefaie W, Abdelhafez MS, Badawy A. Vaginal progesterone for prevention of preterm labor in asymptomatic twin pregnancies with sonographic short cervix: a randomized clinical trial of efficacy and safety. Arch Gynecol Obstet 2016; 293: 61-67

[84] Rode L, Klein K, Nicolaides KH et al. Prevention of preterm delivery in twin gestations (PREDICT): a multicenter, randomized, placebo-controlled trial on the effect of vaginal micronized progesterone. Ultrasound Obstet Gynecol 2011; 38: 272-280

[85] Romero R, Conde-Agudelo A, El-Refaie W et al. Vaginal progesterone decreases preterm birth and neonatal morbidity and mortality in women with a twin gestation and a short cervix: an updated meta-analysis of individual patient data. Ultrasound Obstet Gynecol 2017; 49: 303-314

[86] Berghella V, Odibo AO, To MS et al. Cerclage for short cervix on ultrasonography: Meta-analysis of trials using individual patient-level data. Obstet Gynecol 2005; 106: 181-189

[87] Rust OA, Atlas RO, Reed J et al. Revisiting the short cervix detected by transvaginal ultrasound in the second trimester: why cerclage therapy may not help. Am J Obstet Gynecol 2001; 185: 1098-1105

[88] Berghella V, Odibo AO, Tolosa JE. Cerclage for prevention of preterm birth in women with a short cervix found on transvaginal ultrasound examination: a randomized trial. Am J Obstet Gynecol 2004; 191: 13111317

[89] Althuisius SM, Dekker GA, Hummel P et al. Final results of the Cervical Incompetence Prevention Randomized Cerclage Trial (CIPRACT): therapeutic cerclage with bed rest versus bed rest alone. Am J Obstet Gynecol 2001; 185: 1106-1112 
[90] Saccone G, Rust O, Althuisius S et al. Cerclage for short cervix in twin pregnancies: systematic review and meta-analysis of randomized trials using individual patient-level data. Acta Obstet Gynecol Scand 2015; 94: 352-358

[91] Liem S, Schuit E, Hegeman M et al. Cervical pessaries for prevention of preterm birth in women with a multiple pregnancy (ProTWIN): a multicentre, open-label randomised controlled trial. Lancet 2013; 382: 1341-1349

[92] Goya M, de la Calle M, Pratcorona L et al.; PECEP-Twins Trial Group. Cervical pessary to prevent preterm birth in women with twin gestation and sonographic short cervix: A multicenter randomized controlled trial (PECEP-Twins). Am J Obstet Gynecol 2016; 214: 145-152

[93] Dang VQ, Nguyen LK, He YTN et al. Cervical pessary versus vaginal progesterone for the prevention of preterm birth in women with a twin pregnancy and a cervix <38 mm: A randomized controlled trial. Am J Obstet Gynecol 2018; 218: 603-604

[94] Nicolaides KH, Syngelaki A, Poon LC et al. Cervical pessary placement for prevention of preterm birth in unselected twin pregnancies: a randomized controlled trial. Am J Obstet Gynecol 2016; 214: 3.e1-3.e9

[95] Berghella V, Dugoff L, Ludmir J. Prevention of preterm birth with pessary in twins (PoPPT): a randomized controlled trial. Ultrasound Obstet Gynecol 2017; 49: 567-572

[96] Carreras E. Cervical pessary for preventing birth in Twin pregnancies with maternal short cervix after an episode of threatened preterm labour: randomised control trial. Abstract, 17th World Congress in Fetal Medicine, Athen 2018

[97] Rebarber A, Bender S, Silverstein M et al. Outcomes of emergency or physical examination-indicated cerclage in twin pregnancies compared to singleton pregnancies. Eur J Obstet Gynecol Reprod Biol 2014; 173: 43-47

[98] Miller ES, Rajan PV, Grobman WA. Outcomes after physical examination-indicated cerclage in twin gestations. Am J Obstet Gynecol 2014; 211: 46.e1-46.e5

[99] Roman A, Rochelson B, Fox NS et al. Efficacy of ultrasound-indicated cerclage in twin pregnancies. Am J Obstet Gynecol 2015; 212: 788. e1-788.e6

[100] Park JY, Cho SH, Jeon SJ et al. Outcomes of physical examination-indicated cerclage in twin pregnancies with acute cervical insufficiency compared to singleton pregnancies. J Perinat Med 2018; 46: 845-852

[101] van der Heyden JL. Preterm prelabor rupture of membranes: different gestational ages, different problems [Thesis]. Maastricht: Maastricht University; 2014

[102] Mercer BM, Goldenberg RL, Moawad AH et al. The preterm prediction study: effect of gestational age and cause of preterm birth on subsequent obstetric outcome. National Institute of Child Health and Human Development Maternal-Fetal Medicine Units Network. Am J Obstet Gynecol 1999; 181: 1216-1221

[103] Asrat T, Lewis DF, Garite TJ et al. Rate of recurrence of preterm premature rupture of membranes in consecutive pregnancies. Am J Obstet Gynecol 1991; 165: 1111-1115

[104] Ramsauer B, Vidaeff AC, Hosli I et al. The diagnosis of rupture of fetal membranes (ROM): a meta-analysis. J Perinat Med 2013; 41: 233-240

[105] Palacio M, Kuhnert M, Berger R et al. Meta-analysis of studies on biochemical marker tests for the diagnosis of premature rupture of membranes: comparison of performance indexes. BMC Pregnancy Childbirth 2014; 14: 183

[106] Munson LA, Graham A, Koos BJ et al. Is there a need for digital examination in patients with spontaneous rupture of the membranes? Am J Obstet Gynecol 1985; 153: 562-563

[107] Alexander JM, Mercer BM, Miodovnik M et al. The impact of digital cervical examination on expectantly managed preterm rupture of membranes. Am J Obstet Gynecol 2000; 183: 1003-1007
[108] Mercer BM, Miodovnik M, Thurnau GR et al. Antibiotic therapy for reduction of infant morbidity after preterm premature rupture of the membranes. A randomized controlled trial. National Institute of Child Health and Human Development Maternal-Fetal Medicine Units Network. JAMA 1997; 278: 989-995

[109] Melamed N, Hadar E, Ben-Haroush A et al. Factors affecting the duration of the latency period in preterm premature rupture of membranes. J Matern Fetal Neonatal Med 2009; 22: 1051-1056

[110] Garite T], Freeman RK. Chorioamnionitis in the preterm gestation. Obstet Gynecol 1982; 59: 539-545

[111] Beydoun SN, Yasin SY. Premature rupture of the membranes before 28 weeks: Conservative management. Am J Obstet Gynecol 1986; 155: 471-479

[112] Major CA, de Veciana M, Lewis DF et al. Preterm premature rupture of membranes and abruptio placentae: is there an association between these pregnancy complications? Am J Obstet Gynecol 1995; 172 (2 Pt 1): 672-676

[113] Ananth CV, Oyelese Y, Srinivas N et al. Preterm premature rupture of membranes, intrauterine infection, and oligohydramnios: Risk factors for placental abruption. Obstet Gynecol 2004; 104: 71-77

[114] Soraisham AS, Singhal N, McMillan DD et al. A multicenter study on the clinical outcome of chorioamnionitis in preterm infants. Am J Obstet Gynecol 2009; 200: 372.e1-372.e6

[115] Lewis DF, Robichaux AG, Jaekle RK et al. Expectant management of preterm premature rupture of membranes and nonvertex presentation: what are the risks? Am J Obstet Gynecol 2007; 196: 6

[116] Higgins RD, Saade G, Polin RA et al. Evaluation and Management of Women and Newborns With a Maternal Diagnosis of Chorioamnionitis: Summary of a Workshop. Obstet Gynecol 2016; 127: 426-436

[117] Gibbs RS, Blanco JD, St Clair PJ et al. Quantitative bacteriology of amniotic fluid from women with clinical intraamniotic infection at term. J Infect Dis 1982; 145: 1-8

[118] Silver RK, Gibbs RS, Castillo M. Effect of amniotic fluid bacteria on the course of labor in nulliparous women at term. Obstet Gynecol 1986; 68: 587-592

[119] Blanco JD, Gibbs RS, Malherbe $\mathrm{H}$ et al. A controlled study of genita mycoplasmas in amniotic fluid from patients with intra-amniotic infection. J Infect Dis 1983; 147: 650-653

[120] Gibbs RS, Blanco JD, St. Clair PJ et al. Mycoplasma hominis and intrauterine infection in late pregnancy. Sex Transm Dis 1983; 10: 303-306

[121] Gibbs RS, Blanco JD, Lipscomb K et al. Asymptomatic parturient women with high-virulence bacteria in the amniotic fluid. Am J Obstet Gynecol 1985; 152 (6 Pt 1): 650-654

[122] Hauth JC, Gilstrap LC, Hankins GDV et al. Term maternal and neonata complications of acute chorioamnionitis. Obstet Gynecol 1985; 66: 59-62

[123] Gomez R, Romero R, Ghezzi F et al. The fetal inflammatory response syndrome. Am J Obstet Gynecol 1998; 179: 194-202

[124] Hofer N, Kothari R, Morris N et al. The fetal inflammatory response syndrome is a risk factor for morbidity in preterm neonates. Am J Obstet Gynecol 2013; 209: 542.e1-542.e11

[125] Waters TP, Mercer BM. The management of preterm premature rup ture of the membranes near the limit of fetal viability. Am J Obstet Gynecol 2009; 201: 230-240

[126] van Teeffelen AS, van der Ham DP, Oei SG et al. The accuracy of clinical parameters in the prediction of perinatal pulmonary hypoplasia secondary to midtrimester prelabour rupture of fetal membranes: a meta-analysis. Eur J Obstet Gynecol Reprod Biol 2010; 148: 3-12

[127] Blott M, Greenough A. Neonatal outcome after prolonged rupture of the membranes starting in the second trimester. Arch Dis Child 1988; 63: $1146-1150$ 
[128] [Anonymous]. Obstetric Care Consensus No. 6 Summary: Periviable Birth. Obstet Gynecol 2017; 130: 926-928

[129] [Anonymous]. ACOG Practice Bulletin No. 188: Prelabor Rupture of Membranes. Obstet Gynecol 2018; 131: e14

[130] Bond DM, Middleton P, Levett KM et al. Planned early birth versus expectant management for women with preterm prelabour rupture of membranes prior to 37 weeks' gestation for improving pregnancy outcome. Cochrane Database Syst Rev 2017; (3): CD004735

[131] Kenyon S, Boulvain M, Neilson JP. Antibiotics for preterm rupture of membranes. Cochrane Database Syst Rev 2013; (12): CD001058

[132] Mackeen AD, Seibel-Seamon J, Muhammad J et al. Tocolytics for preterm premature rupture of membranes. Cochrane Database Syst Rev 2014; (2): CD007062

[133] Tita AT, Andrews WW. Diagnosis and management of clinical chorioamnionitis. Clin Perinatol 2010; 37: 339-354

[134] Kunze M, Klar M, Morfeld CA et al. Cytokines in noninvasively obtained amniotic fluid as predictors of fetal inflammatory response syndrome. Am J Obstet Gynecol 2016; 215: 96.e1-96.e98

[135] Musilova I, Kacerovsky M, Stepan M et al. Maternal serum C-reactive protein concentration and intra-amniotic inflammation in women with preterm prelabor rupture of membranes. PLoS One 2017; 12: e0182731

[136] Mercer BM, Rabello YA, Thurnau GR et al. The NICHD-MFMU antibiotic treatment of preterm PROM study: impact of initial amniotic fluid volume on pregnancy outcome. Am J Obstet Gynecol 2006; 194: 438445

[137] Abramowicz JS, Sherer DM, Warsof SL et al. Fetoplacental and uteroplacental Doppler blood flow velocity analysis in premature rupture of membranes. Am J Perinatol 1992; 9: 353-356

[138] Dudley J, Malcolm G, Ellwood D. Amniocentesis in the management of preterm premature rupture of the membranes. Aust N Z J Obstet Gynaecol 1991; 31: 331-336

[139] Musilova I, Bestvina T, Hudeckova M et al. Vaginal fluid interleukin-6 concentrations as a point-of-care test is of value in women with preterm prelabor rupture of membranes. Am J Obstet Gynecol 2016; 215: 619.e1-619.e12

[140] Hofmeyr G], Eke AC, Lawrie TA. Amnioinfusion for third trimester preterm premature rupture of membranes. Cochrane Database Syst Rev 2014; (3): CD000942
[141] Morris JM, Roberts CL, Bowen JR et al. Immediate delivery compared with expectant management after preterm pre-labour rupture of the membranes close to term (PPROMT trial): a randomised controlled trial. Lancet 2016; 387: 444-452

[142] van der Ham DP, Vijgen SM, Nijhuis JG et al. Induction of labor versus expectant management in women with preterm prelabor rupture of membranes between 34 and 37 weeks: a randomized controlled trial. PLoS Med 2012; 9: e1001208

[143] van der Ham DP, van der Heyden JL, Opmeer BC et al. Management of late-preterm premature rupture of membranes: the PPROMEXIL-2 trial. Am J Obstet Gynecol 2012; 207: 276.e1-276.e10

[144] Tajik P, van der Ham DP, Zafarmand MH et al. Using vaginal Group B Streptococcus colonisation in women with preterm premature rupture of membranes to guide the decision for immediate delivery: a secondary analysis of the PPROMEXIL trials. BJOG 2014; 121: 1263-1272; discussion 1273

[145] Quist-Nelson J, de Ruigh AA, Seidler AL et al.; Preterm Premature Rupture of Membranes Meta-analysis (PPROMM) Collaboration. Immediate Delivery Compared With Expectant Management in Late Preterm Prelabor Rupture of Membranes: An Individual Participant Data Metaanalysis. Obstet Gynecol 2018; 131: 269-279

[146] Brisch KH. Prävention durch prä- und postnatale Psychotherapie. In: Brisch K-H, Hellbrügge T, Hrsg. Die Anfänge der Eltern-Kind-Bindung. Schwangerschaft, Geburt und Psychotherapie. Stuttgart: Klett-Cotta; 2007: 271-303

[147] Wehkamp KH. Psychosoziale Ätiologie und psychosomatische Betreuung bei vorzeitigen Wehen. Arch Gynecol Obstet 1987; 242: 712-713

[148] Mahler G, Grab D, Kächele H, Kreienberg R, Zimmer I. Geeignete Bewältigung bei drohender Frühgeburt - Expertenrating. In: Rohde A, Riecher-Rössler A, Hrsg. Psychische Erkrankungen bei Frauen - Psychiatrie und Psychosomatik in der Gynäkologie. Regensburg: S. Roderer Verlag; 2001: 226-232

[149] Fisch S, Klapp C, Bergmann R et al. Psychosoziales Frühwarnsystem Babylotse Plus - Untersuchung der diagnostischen Genauigkeit des Babylotse Plus Screeningbogens. Z Geburtshilfe Neonatol 2015: 219 P201_214

[150] Frühgeborene: Für Familien. Online: https://www.fruehgeborene.de/ fuer-familien; last access: 28.04.2019

[151] Frühe Hilfen. Online: https://www.fruehehilfen.de; last access: 28.04.2019 


\section{Guideline Program}

\section{Editors}

Leading Professional Medical Associations

\section{TS}

German Society of Gynecology and Obstetrics (Deutsche Gesellschaft für Gynäkologie und Geburtshilfe e. V. [DGGG])

Head Office of DGGG and Professional Societies Hausvogteiplatz 12, DE-10117 Berlin info@dggg.de

http://www.dggg.de/

\section{President of DGGG}

Prof. Dr. med. Anton Scharl

Direktor der Frauenkliniken

Klinikum St. Marien Amberg

Mariahilfbergweg 7, DE-92224 Amberg

Kliniken Nordoberpfalz AG

Söllnerstraße 16, DE-92637 Weiden

\section{DGGG Guidelines Representatives}

Prof. Dr. med. Matthias W. Beckmann Universitätsklinikum Erlangen, Frauenklinik Universitätsstraße 21-23, DE-91054 Erlangen

Prof. Dr. med. Erich-Franz Solomayer Universitätsklinikum des Saarlandes Geburtshilfe und Reproduktionsmedizin Kirrberger Straße, Gebäude 9, DE-66421 Homburg

\section{Guidelines Coordination}

Dr. med. Paul Gaß, Dr. med. Gregor Olmes, Christina Meixner Universitätsklinikum Erlangen, Frauenklinik Universitätsstraße 21-23, DE-91054 Erlangen fk-dggg-leitlinien@uk-erlangen.de http://www.dggg.de/leitlinienstellungnahmen

\section{OEGGG}

Austrian Society of Gynecology and Obstetrics (Österreichische Gesellschaft für Gynäkologie und Geburtshilfe [OEGGG])

Frankgasse 8, AT-1090 Wien

stephanie.leutgeb@oeggg.at

http://www.oeggg.at

\section{President of OEGGG}

Prof. Dr. med. Petra Kohlberger

Universitätsklinik für Frauenheilkunde Wien

Währinger Gürtel 18-20, AT-1090 Wien

\section{OEGGG Guidelines Representatives}

Prof. Dr. med. Karl Tamussino

Universitätsklinik für Frauenheilkunde und Geburtshilfe Graz Auenbruggerplatz 14, AT-8036 Graz

Prof. Dr. med. Hanns Helmer Universitätsklinik für Frauenheilkunde Wien Währinger Gürtel 18-20, AT-1090 Wien

\section{gynécologie suisse}

Swiss Society of Gynecology and Obstetrics (Schweizerische Gesellschaft für Gynäkologie und Geburtshilfe [SGGG])

Gynécologie Suisse SGGG Altenbergstraße 29, Postfach 6, CH-3000 Bern 8 sekretariat@sggg.ch http://www.sggg.ch/

\section{President in SGGG}

Dr. med. Irène Dingeldein

Längmatt 32, CH-3280 Murten

\section{SGGG Guidelines Representatives}

Prof. Dr. med. Daniel Surbek Universitätsklinik für Frauenheilkunde Geburtshilfe und feto-maternale Medizin Inselspital Bern Effingerstraße 102, CH-3010 Bern

Prof. Dr. med. René Hornung Kantonsspital St. Gallen, Frauenklinik Rorschacher Straße 95, CH-9007 St. Gallen 